\title{
WINNING BY LOSING: \\ EVIDENCE ON THE LONG-RUN EFFECTS OF MERGERS
}

\author{
Ulrike Malmendier \\ Enrico Moretti \\ Florian S. Peters \\ Working Paper 18024 \\ http://www.nber.org/papers/w18024 \\ NATIONAL BUREAU OF ECONOMIC RESEARCH \\ 1050 Massachusetts Avenue \\ Cambridge, MA 02138 \\ April 2012
}

We thank Jeff Zeidel and seminar participants at Amsterdam, Chicago Booth, DePaul, LSE, Luxembourg School of Finance, MIT, NYU, Ohio State University, Princeton, Tinbergen Institute, Yale, and at the AFA, EFA, FIRS, and the NBER Summer Institute for valuable comments. We thank Zach Liscow and Jonas Sobott for excellent research assistance. The views expressed herein are those of the authors and do not necessarily reflect the views of the National Bureau of Economic Research.

NBER working papers are circulated for discussion and comment purposes. They have not been peer-reviewed or been subject to the review by the NBER Board of Directors that accompanies official NBER publications.

(C) 2012 by Ulrike Malmendier, Enrico Moretti, and Florian S. Peters. All rights reserved. Short sections of text, not to exceed two paragraphs, may be quoted without explicit permission provided that full credit, including $(\odot$ notice, is given to the source. 
Winning by Losing: Evidence on the Long-Run Effects of Mergers

Ulrike Malmendier, Enrico Moretti, and Florian S. Peters

NBER Working Paper No. 18024

April 2012, Revised August 2016

JEL No. G02,G14,G34

\begin{abstract}
$\underline{\text { ABSTRACT }}$
Do acquirors profit from acquisitions, or do CEOs overbid and destroy shareholder value? We propose a novel approach to measuring the long-run returns to mergers. In a new data set of close bidding contests we use losers' post-merger performance to construct the counterfactual performance of winners had they not won the contest. We find that winner and loser returns are closely comoving in the years before the contest, providing support for our approach to identification. After the merger, they diverge: Winners underperform losers by 24 percent over the following three years in the U.S. sample, and by 14 percent in the international sample. Merger characteristics commonly associated with underperformance, such as acquiror size, acquiror $\mathrm{Q}$, or stock financing do not explain the underperformance. Instead, the large underperformance of cash-financed mergers and their post-merger increase in leverage is consistent with behavioral and practitioner views on the determinants of merger outcomes. We also show that commonly used methodologies such as the announcement effect fail to identify the acquiror underperformance.
\end{abstract}

Ulrike Malmendier

Department of Economics

549 Evans Hall \# 3880

University of California, Berkeley

Berkeley, CA 94720-3880

and NBER

ulrike@econ.berkeley.edu

Enrico Moretti

University of California, Berkeley

Department of Economics

549 Evans Hall

Berkeley, CA 94720-3880

and NBER

moretti@econ.berkeley.edu
Florian S. Peters

Finance Group

University of Amsterdam

Roetersstraat 11, 1018 WB Amsterdam

The Netherlands

and Duisenberg School of Finance

f.s.peters@uva.nl 
Do acquiring companies profit from acquisitions, or do acquirors overbid and destroy shareholder value? The negative stock-market reactions to a large number of merger announcements (see, e.g., Moeller, Schlingemann, and Stulz (2005)) have attracted considerable attention to this question. Researchers have interpreted such findings as evidence of empire building (Jensen (1986)), other misaligned personal objectives of CEOs (Morck, Shleifer, and Vishny (1990)), or CEOs' overconfidence (Roll (1986); Malmendier and Tate (2008)). A major obstacle in evaluating mergers is the difficulty of obtaining unbiased estimates of the value they create or destroy. The most common approach is to use stock price changes on the day of the announcement; but announcement returns may be biased due to price pressure around mergers, information revealed in the merger bid, or market inefficiencies. ${ }^{1}$ Another approach is to calculate long-run abnormal returns; but those may be biased due to unobserved differences between the firms that merge and the benchmark firms that do not. For example, when an acquiror's stock price declines during the months following a merger, it is possile that it would have declined even more had the merger not taken place (see Shleifer and Vishny (2003) and Rhodes-Kropf and Viswanathan (2004)). Generally speaking, the issue is that it is difficult to find a valid control group to whom we can compare acquiring firms, as the latter are a selected group and engage in mergers at selected points in time.

In this paper, we use merger contests to evaluate the long-run effects of mergers on acquiror returns. We collect data on all U.S. mergers with concurrent bids of at least two potential acquirors since 1985. We also construct a broad international data set on bidding contests. The basic approach to identification is to use the post-merger performance of losers to calculate the counterfactual performance of the matched winners had they not undertaken the merger. To maximize the similarity between winning and losing bidders, we focus on

\footnotetext{
${ }^{1}$ See, for example, Mitchell, Pulvino, and Stafford (2004); Asquith, Bruner, and Mullins Jr (1987); and Loughran and Vijh (1997).
} 
protracted contests, i.e., contests where bidders actively compete, for example by making multiple offers and counter-offers. Participation in such a bidding contest provides a novel matching criterion, over and above the usual market-, industry-, and firm-level observable characteristics.

Our approach offers an improvement over existing analyses if winners are more similar to losers than to the average firm in the market or other previously used control groups. For example, our approach may account for strategic considerations that would lead firms to attempt a specific takeover at a specific point in time but that are hard to control for with the standard set of financial variables. Our approach has the disadvantage that it is restricted to merger contests. We cannot speak to the value generated in a broader set of mergers. The methodological implications of our findings, however, go beyond the sample of contests. By comparing our estimates to estimates based on existing methodologies, we provide evidence on the biases embedded in other approaches and their potential magnitude.

We find that winners' and losers' have generally similar observable characteristics before the merger, and are more similar than winners are to the average U.S. firm. In particular, before the merger, winners and losers have similar Tobin's Q, PP\&E, profitability, book leverage, and market leverage. Most importantly, winners and losers display very similar stock market performance in the months leading up to the announcement: Their buy-andhold abnormal returns closely track each other during the 36 months before the merger announcement. Stock prices are particularly suitable for probing the validity of our identifying assumption because stock valuations are forward looking and capture pre-merger market expectations about future profitability. In addition, analyst forecasts of winners' and losers' future earnings-to-price ratios are similar. Thus, consistent with our identifying assumption, both the market overall and the experts appear to have similar expectations about the future profitability of winners and losers before the merger. 
After the merger, however, losers significantly outperform winners. The estimated effect for U.S. mergers is economically large, a 23.7 to 35.5 percent difference in buy-and-hold abnormal returns over the next three years, depending on the sample refinement and abnormal return calculation. These differences in post-merger performance between winners and losers cannot be attributed to changes in the risk profile of winners relative to losers. When we adjust for changes in risk exposure, the results remain unchanged. Outside the U.S., contested mergers generate less underperformance. We estimate an effect of $13.6 \%$ in the international sample.

We explore the role of a number of firm- and deal-specific characteristics that are commonly associated with merger performance. In contrast to prior literature, we do not find that high acquiror Q, large acquiror or target size, or stock financing predict underperformance. To the contrary, once the acquiror is matched against a similar bidder, the estimated post-merger underperformance is more pronounced among acquirors with belowmedian market-to-book ratio, size, or target size, though the difference to the respective above-median samples is not significant. The underperformance of cash-financed mergers is estimated to be almost three times as large $(-56.45 \%, p$-value: 0.01$)$ as the underperformance of stock-financed mergers $(-20.45 \%, p$-value: 0.08$)$, though the difference also fails to be significant ( $p$-value: 0.15 ). Post-merger performance does not vary significantly by the public or private nature of the target, diversification, number of bidders, or size of the offer premium. Only hostile bids emerge as predicting significantly larger post-merger underperformance than friendly bids. We also find that winners tend to build up significantly more leverage than losers post-merger.

The differences in findings relative to prior literature, notably the lack of predictive power of high acquiror-Q and the strong underperformance of cash mergers, might of course reflect properties of our specific sample of contested mergers; but they could also reflect the 
difference in methodology. For instance, the prior finding that highly valued acquirors underperform relative to the market and characteristics-matched benchmarks (Rau and Vermaelen (1998)) may be subject to selection concerns. As pointed out by Shleifer and Vishny (2003) and Rhodes-Kropf and Viswanathan (2004), highly valued firms may choose to acquire less highly valued targets in order to attenuate the reversal in their (over-)valuation. In this case, the subsequent decline in acquirors' market valuation is not caused by the merger; it would have occurred even in the absence of the takeover. Our setting alleviates such selection concerns since highly valued winners are benchmarked against similarly-valued losers competing for the same target. Indeed, we do not find underperformance of high-Q acquirors relative to their losing competitors.

The finding of a large underperformance of cash-financed mergers is consistent with the practitioner view that cash mergers are driven by the desire of target management to cash out, without regard for future economic value creation. It is also consistent with the behavioral literature pointing to the role of CEO overconfidence, as overconfident CEOs display a strong preference for cash financing (Malmendier and Tate (2008)). Consistent with both views, we uncover a sharp divergence in capital structure between winners and losers following the merger: Winners have significantly higher leverage ratios than losers, which may affect the long-term health of the merged company, or at least the market's view thereof.

Finally, our empirical approach allows us to evaluate existing methods to measure returns to mergers, albeit in the context of our sample of contested mergers. We calculate announcement effects, alphas based on four-factor calendar-time regressions of winner-only portfolios, and winners' long-run buy-and-hold abnormal returns. We find that none of these approaches capture the negative long-run return implications of mergers. Winners' announcement returns both at the initial bid and at the losing bidder's withdrawal are insignificantly negative, 
and winners' four-factor alphas as well as winners' long-run buy-and-hold abnormal returns are insignificantly positive. Moreover, winners' announcement returns display an insignificantly negative correlation with our estimates, i.e., they fail to predict the causal effect of contested mergers even directionally.

This paper relates to a large literature estimating the value created in corporate takeovers. Reviews of the empirical evidence go back to at least Jensen and Ruback (1983) and Roll (1986). More recent assessments are from Andrade, Mitchell, and Stafford (2001) and Betton, Eckbo, and Thorburn (2008). The evidence on the value effects of mergers for acquirors is mixed. Recent studies of acquiror percentage announcement returns find relatively small but statistically significant effects of 0.5-1\% (Moeller, Schlingemann, and Stulz (2004); Betton, Eckbo, and Thorburn (2008)). The analysis of dollar announcement returns (Moeller, Schlingemann, and Stulz (2005)) reveals that a small number of large losses swamp the majority of profitable, but smaller, acquisitions. Studies of long-run post-merger performance suggest that stock mergers and mergers by highly valued acquirors are followed by poor performance (Loughran and Vijh (1997); Rau and Vermaelen (1998)). Industry-specific studies of the long-term consequences of mergers, such as recently Allen, Clark, and Houde (2014) for the mortgage industry and Gowrisankaran, Nevo, and Town (2015) for the hospital industry, tend to focus on the welfare implications for consumers rather than abnormal returns.

Few papers analyze bidding contests. One notable exception is Boone and Mulherin (2008), who identify competing bidders in the private negotiation stage and test whether more bidding competition induces lower bidder returns. They find that this is not the case, consistent with our results for later-stage bidding. Differently from our paper, their analysis does not use a winner-loser comparison. The winner-loser research design is, instead, motivated by Greenstone and Moretti (2004) and Greenstone, Hornbeck, and Moretti (2010), who analyze bids by local governments to attract "million-dollar plants" to their jurisdiction 
by comparing winners and losers. Relative to their county-level analysis, mergers allow for considerably more convincing controls of bidder heterogeneity. In contrast to measures such as firm productivity or labor earnings, stock prices incorporate not just current conditions but also expectations about future performance. Our identification strategy also relates to Savor and $\mathrm{Lu}$ (2009), who use a small sample of failed acquisitions to construct a counterfactual. On the theoretical side, Dimopoulos and Sacchetto (2014) features an auction model and structural estimation relating bidder behavior to subsequent abnormal returns.

The paper proceeds as follows. Section I describes the data. Section II explains the econometric model. Section III presents the main estimates of the merger effects, and Section IV explores possible channels. Section V compares the winner-loser methodology with existing methodologies. Section VI concludes.

\section{Data}

\section{A. Sample Construction}

Our data combine information on merger contests from the Thomson One Mergers and Acquisitions database with financial and accounting information from CRSP, Compustat, Compustat Global, Datastream as well as analyst forecast data from I/B/E/S.

Thomson One records public and binding acquisition bids. ${ }^{2}$ We collect all contested bids made by public U.S.-listed firms between January 1, 1985 and December 31, 2012. We exclude privately held and government-owned firms, mutually owned companies, subsidiaries, and firms whose status Thomson cannot reliably identify. We also exclude white knights since they likely lack ex-ante similarity with other bidders in their success chances and hence do not provide a plausible hypothetical counterfactual. To identify contested mergers, we use

\footnotetext{
${ }^{2}$ We do not consider non-binding bids, which are often made during the initial, private stage of the takeover bidding process (see Boone and Mulherin (2007)), since bidders with a serious interest in the acquisition are more likely to be similar ex ante, consistent with our identification strategy.
} 
Thomson One's competing bid flag. We verify that all bids for a given target that are flagged as contested in the Thomson One database were indeed valid in overlapping time periods. In other words, we require that the period between announcement of the winning bid and completion of the merger overlaps with the period between announcement and withdrawal of the losing bids. We classify the company that succeeds in completing the merger as the winner, and all other bidders as losers. In three cases, we find that Thomson erroneously assigns two winners, and we identify the unique winner using a news wire search. A detailed description of the sample construction and of all variables is contained in the Appendix.

For each contest and bidder, we merge the Thomson data with financial and accounting information from the CRSP Monthly Stock and the CRSP/Compustat Merged databases, using monthly data for stock returns, and both quarterly and yearly data for accounting items from three years before to three years after the contest. We eliminate observations that can or should not be matched, such as repeated bids of the same bidder for the same target, contests that are not completed, or firms without CRSP permno. At the same time, we take caution to reduce survivorship bias. When bidders disappear from CRSP in the three-year period after a merger due to delisting, we calculate the return implications of the delisting events for shareholders using all delisting information available in CRSP. (Details are in the Appendix). The final sample, which we denote as the Full Sample, contains 16, 776 event-time observations from 233 bidders, 112 winners and 121 losers. Table A-I summarizes the construction of our data set. Appendix-Figure A-1 shows the frequency distribution of contests over the sample period, and illustrates the spikes in merger activity during the mid-1980s and mid-1990s.

In addition, we construct a "refined" version of the Full Sample. We manually search for press mention of each bid reported in the Thomson data in the Financial Times, Wall Street Journal, and The Washington Post. We are able to find press mentions for 194 out of the 
233 bids in the Full Sample. For 180 bids ( 87 contests, with 87 winnings bids and 93 losing bids), at least one article mentions the competing bids identified by Thomson. We refer to this latter sample as the Contest Coverage Sample. We estimate our empirical model both on the Full Sample and on this smaller Contest Coverage Sample.

We supplement the merger and stock data with analyst forecasts from I/B/E/S. We extract two-years-ahead consensus (mean) earnings forecasts for the 36 months before (and, for completeness, the 36 months after) the merger from the I/B/E/S summary history file using the 8-digit CUSIP as identifier. ${ }^{3}$ We construct the forecasted earnings-to-price ratios as the consensus forecast divided by the stock price at the end of the month. Our sample includes forecasts for 180 firms, $82.2 \%$ of our total sample. ${ }^{4}$

We also test whether the estimated merger effects are present in a broader international sample. We include bids from companies that are headquartered outside North America. The vast majority of contested mergers and acquisitions outside North America that are recorded in Thomson One come from ten additional countries: Australia, France, Germany, Italy, Japan, the Netherlands, Spain, Switzerland, Sweden, and the United Kingdom. Including the U.S. and Canada, these countries cover more than $90 \%$ of all contested bids recorded in Thomson One. For these international cases, we turn to Compustat Global and Datastream for the corresponding stock data, as described in more detail in the Appendix. Our final International Sample contains an additional 72 contests and 152 bids (see Appendix-Table A-II).

We acknowledge that the data for international bidders is significantly less reliable and coverage is much less comprehensive than that of North American firms, as already discussed

\footnotetext{
${ }^{3}$ In addition to the mean (MEANEST), we also extract the median forecast of all analysts covering the firm (MEDEST) as well as forecasts of various other horizons, all of which yield very similar results.

${ }^{4}$ Consensus forecasts are not necessarily available for every month within the $+/$ - three years around a merger. On average, 171 firms are covered in each event-time period. As in previous literature, we drop observations with negative forecasted earnings (see, e.g., Richardson, Sloan, and You (2011)).
} 
in prior research on similar data (e.g., Ince and Porter (2006)), in particular for data prior to the year 2000. We attempt to address these concerns and minimize the effect of noise by winsorizing BHARs at the 1\%-level when we use the International Sample. Moreover, we will generally focus our analysis on the two North American samples.

The contest focus of our analysis requires a specific data architecture. For all three data sets, we construct an event time variable $t$ that counts the months relative to a contest. As illustrated in Figure 1(a), we set $t=0$ at the end of the month preceding the start of the contest, i.e., preceding the earliest bid. The end of the month prior to that is $t=-1$; the end of the month before that is $t=-2$, etc. Going forward, we set $t=+1$ at the end of the month in which the contest ends, that is, in which the merger is completed. The end of the following month is +2 , the end of the month after that is +3 , etc. Hence, event-time periods before and after the merger contest are exactly one month long, but the period from $t=0$ to $t=1$ is of variable length, depending on the duration of the merger contest. Figure 1(b) provides a concrete example from our data, the merger contest between Westcott Communications and Automatic Data Processing for Sandy Corporation.

[Figure 1 approximately here]

\section{B. Summary Statistics}

Table I provides the summary statistics of our main data, the Full Sample. The bidder statistics (Panel A) are based on balance sheet and income data from the end of the fiscal year preceding the contest. The first three rows indicate that both winners and losers are large compared to the average Compustat firm. ${ }^{5}$ This reflects the fact that acquiring (and public) firms tend to be larger than non-acquiring (and private) firms. The table also shows that winners tend to be larger than losers, though the size difference is only marginally

\footnotetext{
${ }^{5}$ Average total assets of Compustat firms during our sample period are $\$ 5.3 \mathrm{bn}$; the median is $\$ 170.7 \mathrm{~m}$.
} 
significant, and small compared to the difference between the average acquiring and nonacquiring firm in Compustat. The differences between winners and losers in terms of firm characteristics such as Tobin's Q, PP\&E, profitability, book leverage, and market leverage are very small and statistically insignificant. The similarity of winners and losers in observable characteristics is a first indication that losers may be a valid counterfactual for winners.

The last two rows of Panel A report the three-day announcement CARs, in percentage and in dollar terms. Percentage announcement returns are negative for winners and zero for losers, but the winner-loser differences are not significant at conventional levels. In contrast, the winner-loser difference in dollar announcement returns is weakly significant.

[Table I approximately here]

Panel B reports deal characteristics of the completed transactions. The first three rows show that the transaction values of contested mergers are large compared to the size of the bidding firms involved, on average 39 percent of the losers' book assets and 24 percent of the winners' book assets. None of the completed deals in our sample results from a tender offer. This is more common in non-contested mergers. Deal attitude (hostile or friendly), and means of payment (stock, cash, or other means) do not differ markedly from those found in uncontested mergers (see, e.g. Betton, Eckbo, and Thorburn (2008)). 80 out of 112 cases involve two competing bidders, 25 cases involve three bidders, and seven contests involve more than three bidders. ${ }^{6}$

The average offer premium in our sample is 63 percent if expressed as a percentage of the target's market capitalization, and 10 percent if expressed as a percentage of the acquiror's market capitalization. We compute the takeover premium as a percentage of the acquiror's

\footnotetext{
${ }^{6}$ Note that our analysis employs a lower number of bidders than those that actually participate in the contest because not all bidders are public firms and, hence, no stock data is available. Moreover, if we do not count bidders with missing stock data, we have 104 contests with two bidders, seven contests with three bidders, and one contest with four bidders.
} 
market capitalization to assess whether overpayment could potentially have a substantial effect on the acquiring shareholders' equity value. In our sample, takover premia are larger than in a typical sample of non-contested bids (for example, 48 percent relative to target value in a sample of 4,889 bids for US targets during 1980-2002, analyzed by Betton, Eckbo, and Thorburn (2008)) and may indicate overbidding, or winner's curse, brought about by the competing offers. Below we explore this possibility in more detail.

\section{Identifying Close Contests}

In our empirical analysis, we seek to distinguish between takeover contests in which winning and losing bidders have a similar ex-ante chance of winning the contest, so called "close contests," and those where the chances differ substantially. We argue that the subsample of close contests provides the setting that most credibly allows for a causal interpretation.

To identify the subset of contests in which all bidders have a significant ex-ante chance of winning, we focus on contests that take a particularly long time to resolve. The idea is that these contests likely feature a back-and-forth of bids, or otherwise a situation in which the identity of the eventual winner is not clear from the beginning. To see this, consider an acquisition contest as akin to an open, ascending auction with multiple bidders. If the target valuations of the two bidders differ substantially, the bidding process is likely to be short because it ends as soon as the winner's bid just exceeds the (much) lower valuation of the losing bidder. In this case, the ex-ante chances of winning are very different for the two bidders, and therefore the loser is unlikely to be a good counterfactual for the winner. In contrast, if both bidders have similar target valuations, the bidding process will likely last longer, because more bidding rounds are necessary before the bidder with the (slightly) lower target valuation drops out of the contest. Hence, empirically, longer contests should involve bidders with more similar target valuations and hence more similar ex-ante chances 
of winning.

To implement this idea, we focus our empirical analysis on contests with above-median duration. Merger contests with above-median duration last six months to over two years, with a mean of 12.79 months. The mean for contests of below-median duration is 4.39 months, which is similar to the duration of non-contested mergers. We also run all of our empirical tests on alternative sample splits, i.e., terciles and quartiles of contest duration. We find similar results on these subsamples (available upon request).

A qualitative and quantitative inspection of press accounts about mergers in the upper and lower half of contest duration confirms the underlying intuition. Using the Financial Times, Wall Street Journal, and The Washington Post articles described above, we find that, in short-duration contests, one bidder typically withdraws the bid quickly after the competing bid comes in, suggesting that the withdrawing company does not see much of a chance to win. By contrast, long-duration contests often involve multiple bidding rounds in which both bidders raise their initial bid in response to the competitor's most recent offer, sometimes several times. In the long-duration half of our sample, $43 \%$ of the bids are withdrawn only after a higher bid by at least one of the potential acquirors. In the short-duration sample, this is the case in just $24 \%$ of the contests. Instead, in the short-duration sample, $62 \%$ of losers withdraw shortly after placement of the competing bid, but only $24 \%$ in the long-duration contests. ${ }^{7}$ The longer duration appears to indicate that neither offer clearly dominates, and that target management or target shareholders take both bids seriously. It is precisely in these contests that we expect the maximum similarity between winners and losers, and hence the loser's performance to provide a valid counterfactual for the winner's performance. In

\footnotetext{
${ }^{7}$ We also check whether the contest duration is driven by the time between withdrawal of the last competing bid and the completion. Though the time from withdrawal of the last competing bid to the completion of the merger is longer for long-duration contests, long- and short-duration contests differ significantly in the time during which at least two bids are active (108 vs 45 days).
} 
Section IILA, we will provide formal tests of winner-loser similarity across contest duration bins which confirm our identifying assumption.

We also estimate models that use an alternative definition of contested mergers. In this alternative set of models, we include contests of any duration and define a fight as "close" if at least one bidder has sweetened its offer in response to a competing bid. As we will discuss in more detail below, these estimates of the merger effect are similar to those reported for our main measure.

\section{Econometric Model}

\section{A. The Effect of Mergers on Acquirors}

We evaluate winner-loser differences in abnormal performance over the three years prior to and the three years after the merger contest using a controlled regression framework. We compute buy-and-hold abnormal returns (BHARs) for each month in the $+/$ - three-year event window separately for each bidder. The BHAR is calculated as the difference between the cumulated bidder stock return and a cumulated benchmark return, starting from 0 at $t=0$. Cumulating forward, this amounts to:

$$
B H A R_{i j t}=\prod_{s=1}^{t}\left(1+r_{i j s}\right)-\prod_{s=1}^{t}\left(1+r_{i j s}^{b m}\right)
$$

where $i$ denotes the bidder, $j$ the bidding contest, $t$ and $s$ index event time, $r_{i j s}$ is the bidder's stock return earned in event period $s$, i.e., over the time interval from $s-1$ to $s$ (including all distributions), and $r_{i j s}^{b m}$ is the benchmark return in event period $s .{ }^{8}$ Recall that event time is defined such that $t=0$ indicates the end of the month preceding the start of the merger contest, and $t=1$ the end of the month of merger completion. Hence, the return

\footnotetext{
${ }^{8}$ Cumulating backward, this corresponds to $B H A R_{i j t}=\prod_{s=0}^{t+1}\left(1+r_{i j s}\right)^{-1}-\prod_{s=0}^{t+1}\left(1+r_{i j s}^{b m}\right)^{-1}$ for $t<0$.
} 
at $t=1$ captures the performance over the whole (variable-length) contest, collapsed into one event period. It includes the stock price reactions at bid announcements as well as at contest resolution. After $t=1$ and before $t=0$, event time proceeds in steps of calendar months and, hence, $r_{i j t}$ corresponds to the respective calendar-month return.

We use three standard benchmarks for normal returns to adjust for systematic differences in asset returns: (1) the value-weighted market return, $r_{m t}$. This is our baseline; (2) the value-weighted industry return, $r_{i k t}$, where $k$ is the industry of bidder $i$ based on the FamaFrench 12-industry classification; and (3) the CAPM expected return, $r_{f t}+\beta_{i j}\left(r_{m t}-r_{f t}\right)$, where $r_{f t}$ is the risk free rate and $\beta_{i j}$ is bidder $i$ 's beta in the event window around contest $j .{ }^{9} \quad$ We call the adjusted performance measures market-adjusted, industry-adjusted, and risk-adjusted BHARs, respectively. Note that the BHARs account for calendar time-specific shocks since they net out the cumulated benchmark return realized over the same calendar period.

When calculating risk-adjusted returns we estimate each bidder's beta separately for the pre- and the post-merger periods based on monthly returns. By doing so, we adjust for the mechanical change of the winner's beta brought about by the merger (from that of the pre-merger, stand-alone company to the weighted average of the acquiror's and the target's beta after the merger).

We evaluate the winner-loser differences in abnormal performance using the following

9 We also use value-weighted, characteristics-matched returns as an alternative benchmark (Daniel, Grinblatt, Titman, and Wermers (1997); Wermers (2004)). These are portfolio returns of firms matched on size, book-to-market, and twelve-month momentum. Our main results become stronger when using characteristics-matched returns. We do not report them in the paper because the latest update of the return data provided by Russ Wermers is from 2012, which further reduces the sample size. 
regression equation, akin to the approach in Greenstone, Hornbeck, and Moretti (2010):

$$
B H A R_{i j t}=\sum_{t^{\prime}=\underline{T}}^{\bar{T}} \pi_{t^{\prime}}^{W} W_{i j t}^{t^{\prime}}+\sum_{t^{\prime}=\underline{T}}^{\bar{T}} \pi_{t^{\prime}}^{L} L_{i j t}^{t^{\prime}}+\eta_{j}+\varepsilon_{i j t} .
$$

The key independent variables are the two sets of indicators. $W_{i j t}^{t^{\prime}}$ and $L_{i j t}^{t^{\prime}}$. $W_{i j t}^{t^{\prime}}$ equals 1 if event time $t$ equals $t^{\prime}$ and bidder $i$ is a winner in contest $j$, i.e., $W_{i j t}^{t^{\prime}}=1_{\left\{t=t^{\prime} \text { and } i \text { wins contest } j\right\}}$.

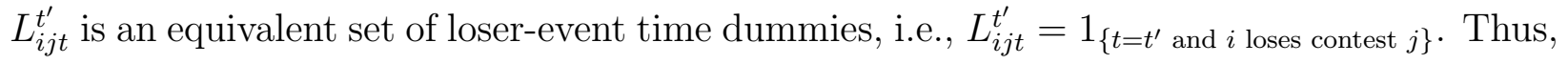
our specification allows the effects of the winner and of the loser status to vary with event time, and the coefficients $\pi_{t^{\prime}}^{W}\left(\pi_{t^{\prime}}^{L}\right)$ measure the average winner (loser) return at event time $t^{\prime}$. For example, $\pi_{3}^{W}$ is the conditional mean of the winners' BHARs three months after the end of the bidding contest, and $\pi_{3}^{L}$ is the conditional mean of the loser BHARs three months after the merger. ${ }^{10}$

The vector $\eta_{j}$ is a full set of contest fixed effects, i.e., of indicator variables for each merger contest, and hence adjusts for all case-specific differences (all fixed characteristics in each group of contestants), and $\varepsilon_{i j t}$ is a stochastic error term. The inclusion of case fixed effects guarantees that the $\pi$-series are identified from comparisons within a winner-loser pair. Thus, we retain the intuitive appeal of pairwise differencing in a regression framework. We also note that the inclusion of calendar year-month fixed effects to account for time varying shocks is redundant when using abnormal returns because abnormal returns already account for period-specific shocks. ${ }^{11}$

Equation (2) yields 72 coefficients for winners and 72 for losers - one for each month in the

\footnotetext{
10 Note that some firms are winners and/or losers more than once, and observations from these firms simultaneously identify multiple $\pi$ 's.

${ }^{11}$ Abnormal returns adjust in fact more finely than fixed effects since the shocks that are subtracted vary with the firm's exposure, e.g., with the firm's risk exposure in the case of risk-adjusted abnormal returns. For completeness, though, we have tested and confirmed that the inclusion of year-month dummies does not alter the economic or statistical significance of the coefficient estimates.
} 
three years prior to and after the merger. This detailed information is useful for graphically assessing the evolution of winners' and losers' performance over time. However, in order to perform statistical tests of the merger effects, we need a more parsimonious version with few interpretable coefficients. We estimate the following piecewise-linear approximation:

$$
\begin{aligned}
\text { BHAR } R_{i j t} & =\alpha_{0}+\alpha_{1} W_{i j t}+\alpha_{2} t_{i j t}+\alpha_{3} t_{i j t} W_{i j t}+\alpha_{4} \text { Post }_{i j t}+\alpha_{5} \text { Post }_{i j t} W_{i j t} \\
& +\alpha_{6} t_{i j t} \text { Post }_{i j t}+\alpha_{7} t_{i j t} \text { Post }_{i j t} W_{i j t}+\eta_{j}+\varepsilon_{i j t} .
\end{aligned}
$$

This specification allows for different levels of loser performance before and after the merger ( $\alpha_{0}$ and $\alpha_{4}$ Post) as well as for winner-loser differences in performance levels pre- and postmerger $\left(\alpha_{1} W\right.$ and $\alpha_{5}$ Post $\left.W\right)$. It also accounts for two separate linear time trends in the pre-merger and post-merger periods ( $\alpha_{2} t$ and $\alpha_{6} t$ Post), and for winners deviating from these trends, separately in the pre-merger and in the post-merger periods $\left(\alpha_{3} t W\right.$ and $\alpha_{7} t$ Post $\left.W\right)$. Finally, the specification retains the contest dummies $\eta_{j}$. We estimate the value effect of mergers as the long-run performance difference between winners and losers at $t=36$, $\hat{\alpha}_{1}+\hat{\alpha}_{5}+35 \cdot\left(\hat{\alpha}_{3}+\hat{\alpha}_{7}\right)$. We account for possible serial correlation and correlation within winner-loser pairs by clustering standard errors by contest.

A major advantage of the regression approach above is that it fully leverages the underlying contest-specific matching of firms and, at the same time, flexibly allows for any remaining differences between matched firms to vary over time. The more standard approach in the literature, running calendar time portfolio regressions, cannot be implemented in our setting. The matching requirements leave us with too few firms to form calendar-month portfolios that are long in the winning bidders' stocks and short in the losing bidders' stocks. The long or short portfolios would often contain just one or otherwise very few stocks. As a result, the estimates would become unreliable and depend on minimum-portfolio requirements. 


\section{B. Is There an Effect of Mergers on Losers?}

An important consideration in assessing our identification strategy is whether the merger affects the loser's profitability directly. For example, the merger might change the loser's market power. Such a "loser effect" is not of concern if losing the merger contest affects the loser in a similar manner as it would have affected the winner had he (counterfactually) lost the contest. However, it is a concern if this hypothesized loser effect were to differ between winners and losers.

Two points are worth mentioning in this respect. First, consider the possibility that a merger hurts the performance of the loser more than it would have hurt the performance of the winner had the winner lost the contest. If this were true, it would strengthen our main finding of a negative merger effect. In this scenario, the measured merger effect would be even more negative in the absence of the loser effect and, hence, our estimates would provide a conservative lower bound. Second, consider the possibility that mergers are more beneficial to the loser than to the winner. For example, consider the scenario discussed by Stigler (1950) in which the acquiror reduces post-merger output to a level below the combined output of its pre-merger parts and industry prices increase. Firms that did not merge may then expand output and profit from the higher prices. ${ }^{12}$ This entire class of models where mergers are not profitable and firms prefer not to merge does not apply in our case. The bidders in our sample engage in deliberate and protracted battles to prevail in the merger.

Overall, we conclude that in our context, loser effects are unlikely to be a concern.

12 For example, the Continental-United and Delta-Northwest airline mergers are expected to benefit the non-merging airlines. Theoretically, in both a Cournot oligopoly model and a differentiated products Bertrand model, the non-merging firm could benefit if the synergy or efficiency effects of the merger are not very large. Salant, Switzer, and Reynolds (1983) conclude that in general, a merger is not profitable in a Cournot oligopoly, with the exception of two duopolists that become a monopoly. Subsequent literature has identified some limits of this result. Deneckere and Davidson (1984) argue that the existence of product differentiation can result in the merged firm producing all the output of its pre-merger parts. Perry and Porter (1985) identify many circumstances in which an incentive to merge exists, even though the product is homogeneous. 


\section{Empirical Results}

\section{A. Are Winners and Losers Comparable?}

Table I indicated that winners and losers have similar observable characteristics, with the exception of a marginal difference in size. In this subsection, we go further in testing whether losers are a valid counterfactual for winners, and test for pre-merger similarities in stock prices. Stock prices are particularly suitable for probing the validity of our identification assumption because they capture pre-merger market expectations about future profitability. Unlike the variables in Table I, which are only about current characteristics, stock valuations are forward looking. Thus, they can help us determine whether winner and loser profitability are comparable not just at the time of the announcement, but also in the foreseeable future. Any difference between winners and losers would indicate that the market expects future profitability to be different even without the merger contest.

Figure 2 plots the series of winner and loser $\pi$-coefficients from regression equation (2), estimated on the sample of close (long-duration) contests for three measures of abnormal performance in Panels (a) to (c) and, for completeness, using raw returns in Panel (d).

[Figure 2 approximately here]

The graphs indicate that winning and losing firms display very similar performance paths in the three years before the contest, irrespective of the measure of performance. It is only after ther merger that winning and losing firms diverge. Statistical tests fail to reject the hypothesis that the pre-merger trends for winners and losers are equal. (The $t$-statistics are $-0.19,-0.08,0.37$, and -0.42 , respectively.)

We perform a similar test using analyst forecasts. Analyst forecasts capture expectations

about future profitability by well informed professional experts. While highly correlated with stock performance, they are not identical. Figure 3 shows analyst earnings forecasts 
(scaled by stock price) separately for winners and losers around the contest. Just as the BHARs in Figure 2 above, the forecasted earnings-to-price ratios are normalized to zero in $t=0$. The figure shows, very similarly to the evidence on stock performance, that the paths of forecasted earnings of winners and losers are closely aligned in the three years before the contest.

[Figure 3 approximately here]

In Section IV, we will also analyze ex-post measures of realized operating performance and find that winners and losers in long-duration contests have very similar levels of, and very similar trends in, operating cash flow in the months leading up to the merger.

The close alignment in the paths of these variables for winners and losers, and in particular in the forward-looking variables, lends further support to the identifying assumption. We can go one step further and conduct an even sharper test by analyzing the pair-specific alignment in paths. In Table II we correlate winners' abnormal performance trends prior to the merger (their pre-merger alphas) with their matched losers' abnormal performance trends over the same period. We estimate bidder-specific pre-merger alphas by regressing the pre-merger abnormal returns of each bidder on a constant, and then regress the winner alphas on matched-loser alphas.

Panel A shows the results for long-duration contests (column 1) and, for comparison, for the short-duration contests (column 2) in the Full Sample. We find that the correlation between pre-merger alphas of winners and losers is high and statistically significant. It is more than twice as large in long-duration contests as in the short-duration contests. A similar pattern can be observed for R-squared. In Panel B, we report the analogous results estimated on the Contest Coverage Sample, for which press reports confirm the contested nature of each deal. The results are even stronger. Going from long to short contests, the correlation 
in alphas and R-squared drops by even more than in the full sample. Thus, the results indicate that winning bidders who experience abnormal run-ups (declines) during the three years preceding the merger are typically challenged by rival bidders who have experienced a similar run-up (decline), and that this similarity is most pronounced in contests of long duration.

These findings speak to the concern that contestants differ in their acquisition motives or prospects. Specifically, one may worry that bidders who are motivated by overvaluation of their own stock, possibly following a pre-merger run-up, systematically differ in their postmerger performance from bidders who did not experience a recent run-up. We find that pre-merger trends of both sets of bidders are closely aligned in the sample of long-duration contests.

[Table II approximately here]

The results for the International Sample in Panel C are less strong. Winners' performance is significantly correlated with the performance of their matched loser, though somewhat less strongly than in the two U.S. samples. This is perhaps not surprising since the International Sample contains bidder pairs with companies from different countries. We therefore consider our estimates of the effect of mergers to be most accurate on the two U.S. samples.

Overall, the evidence presented in this subsection indicates that losers represent a plausible counterfactual for winners in long-duration contests. Before the contest, the market expects them to perform similarly in the future. In addition, winners and losers are similar in terms of accounting measures of profitability and other firm characteristics. 


\section{B. Estimates of the Effect of Mergers}

Figure 2 provides a visual description of our main finding. In the months leading up to the contest, winner and loser performance is quite similar. After the contest, however, winner and loser returns begin to diverge. Losers of a close bidding contest display positive abnormal performance, with an initial jump immediately after the end of the contest, and a continued upward trend in the three years after the merger. In contrast, winners display no or negative abnormal performance after the merger. In other words, the shareholders of the acquiring company would have been better off under the hypothetical counterfactual in which their company lost the merger contest.

Table III quantifies the magnitude of the effect, by showing the coefficient estimates of equation (3). In addition, we report the estimated cumulative merger effect at $t=36$ or three years after the contest at the bottom of the table. We estimate our model separately on all close contests in the Full Sample in column (1), on the Contest Coverage Sample in column (2), and on the International Sample in column (3).

\section{[Table III approximately here]}

For all three samples, Table III reports an insignificant coefficient estimate $\alpha_{3}$, which measures the pre-merger trend difference in winner and loser performance. Consistent with the evidence in Figure 2 and Table II, winner and loser returns are statistically indistinguishable at conventional levels during the 36 months leading up to the merger.

The estimated merger effect, instead, is significantly negative. In the Full Sample, re-

ported in column (1), the cumulative underperformance of winners from the beginning of the contest to the end of three years after merger completion is 24 percent. That is, consistent with the visual evidence, the estimates in the table suggest that in our core sample of long-duration contests, winners fare significantly worse than losers and that the difference 
is statistically significant. In the Contest Coverage Sample, which includes only contests validated by the newspapers articles, the effect is even larger, at 35 percent. Despite being left with a relatively small sample after applying all of the matching criteria, the effect is statistically highly significant. We also note that, in both samples the coefficient $\alpha_{7}$ is insignificantly negative, indicating that the underperformance of winners relative to losers does not decrease over time.

In the International Sample, analyzed in column (3), the estimate of the merger effect is smaller, $-14 \%$, but precise enough to remain statistically significant ( $p$-value: 0.05 ).

We have also re-estimated the model using alternative definitions of stock performance and abnormal returns, mirroring the variations in Panels (b), (c), and (d) of Figure 2. As shown in Table IV, our results are insensitive to employing alternative return adjustments. Hence, in the remainder of the paper, we focus on market-adjusted returns.

\section{[Table IV approximately here]}

As another robustness check, we have also estimated models that use an alternative definition of contested mergers. In this alternative set of models, we include contests of any duration and define a fight as "close" if at least one bidder has sweetened its offer in response to a competing bid. Our estimates are consistent with those reported in Table III. In particular, the cumulative underperformance of winners from the beginning of the contest to the end of three years after merger completion is -30.13 (14.87), -29.38 (16.41), -36.72 (18.42), and -23.75 (16.89) for market-adjusted, industry-adjusted, risk-adjusted, and raw returns (and their standard errors), respectively. ${ }^{13}$

\footnotetext{
${ }^{13}$ For completeness, we report the estimates for the short-duration subsample in Appendix Table A-III. We find no significant differences in post-merger performance between winners and losers. As discussed above, it is unclear how to draw inferences about the causal effect of mergers from this sample of contests. In an attempt to relate our main results to the short-duration estimates, we have also estimated the incremental effect of increasing contest duration by one year. In pooled regressions, we interact all variables with contest
} 


\section{Heterogeneity in the Effect and Possible Explanations}

We have found that the post-merger returns of winners and losers differ substantially. On average, losing appears to be better than winning from the perspective of acquiring-company shareholders. However, this average effect masks significant heterogeneity in the magnitude of the losses.

Figure 4 shows the dispersion of the estimated merger effects in our sample. In this figure each contest is an observation, and the histogram shows the distribution of the estimated long-run winner-loser differences in BHARs across contests.

[Figure 4 approximately here]

The mass of the distribution is shifted to the left of zero. This is not surprising by now, since we have already determined that the effect for the mean contest is negative. But it is also clear that not all mergers result in an equal destruction of value. In our sample, $66 \%$ of mergers have a negative effect, and $34 \%$ have a positive effect. The $25 \%, 50 \%$ (median) and $75 \%$ percentiles are $-68 \%,-19 \%$ and $13 \%$, respectively. Of course part of this dispersion likely reflects small sample noise in our estimates. Intuitively, this noise comes from the fact that we do not know the "true" merger effects, but instead can only estimate them. A weighted version of this distribution - with weights equal to the combined firm value of acquiror and target - is similar, though, indicating that not all the dispersion is noise.

What explains this heterogeneity then? In other words, what features of the acquiror firm, the target firm, or the merger itself are systematically associated with larger or smaller effects? This question is important because it can help us shed light on the economic channels that drive the negative merger-effect estimates.

duration. We find that an increase in contest duration by one year is associated with additional value destruction of 46.20 percent. While these estimates are consistent with our estimates in the long-duration subsample, they also lack a causal interpretation due to differential sorting of winning and losing bidders in the short-duration subsample, and are reported only for completeness. 
Prior literature has associated a number of characteristics with long-term post-merger performance. We can test whether any of these characteristics are systematically correlated with the size of the estimated winner-loser difference and thus help explain our findings.

We first focus on characteristics of the acquiror or the target: the acquiror's market-tobook ratio, acquiror and target size, public versus private nature of the target, and whether acquiror and target operate in different industries. Second, we turn to characteristics of the bidding process, namely the number of bidders, hostility of the bid, the acquisition premium, and the means of payment, Finally, we analyze whether the underperformance in terms of stock price is driven by operating profits or whether it is due to financing structure.

Acquiror $\boldsymbol{Q}$. Prior research indicates that highly-valued acquirors tend to underperform in the long run relative to a characteristics-matched firm portfolio (Rau and Vermaelen (1998)). One concern with the interpretation of this result is that temporarily overvalued firms may choose to acquire less highly valued targets, possibly to attenuate the reversal in their (over-)valuation by means of acquisitions, as pointed out by Shleifer and Vishny (2003) and Rhodes-Kropf and Viswanathan (2004). In this case, the subsequent reversal in acquirors' market valuation is not caused by the merger, but would have occurred even in the absence of the takeover. Our setting, in which we benchmark the winner against the losing bidder, alleviates such selection concerns. As we have shown, winners and losers show close similarity in Tobin's Q before the merger (see Table I), and abnormal pre-merger run-ups or declines in stock price are also very similar in winner-losers pairs (see Table II).

Column (1) of Table V shows how the merger effect varies with the acquiror's Q. The regression adds to our baseline model from equation (3) a full set of interaction terms with a dummy variable indicating the subsample of acquirors with above-median market-to-book ratio. At the bottom of the table, we report the merger effect for acquirors with belowmedian Q, above-median Q, as well as for the difference. The results reveal that there is 
no difference in the merger effect between the overvalued and undervalued acquirors once post-merger performance is compared to a similarly over- or undervalued competing bidder.

[Table V approximately here]

These findings, and also the insignificant merger effect estimated for the high-Q subsample, are interesting in that they imply that previous findings on the 'underperformance' of highly valued acquirors post-merger may have to be interpreted with caution. As indicated above, those prior estimation results might be affected by the lack of a proper counterfactual. Empirically, acquisitions of such firms may appear to be value-destroying when not benchmarked against the right counterfactual. Our approach reveals that, in our sample of contested mergers, mergers of high-Q acquirors do not appear to be value-destroying once they are benchmarked against the close-bidder counterfactual.

Acquiror Size. The role of bidder size as a determinant of the returns to mergers has been documented in numerous studies (Moeller, Schlingemann, and Stulz, 2004; Betton, Eckbo, and Thorburn, 2008; Alexandridis, Fuller, Terhaar, and Travlos, 2013). These studies show that large bidders typically experience worse announcement returns than small bidders. Even though the evidence for long-run performance and its relationship with size is less conclusive, we investigate whether a size effect is present in our winner-loser setting.

Column (2) of Table $\mathrm{V}$ shows that acquiror size is not significantly correlated with longrun post-merger performance. If anything, the effect is opposite to what the prior literature suggests: Long-run merger performance is significantly negative for small acquirors $(-38.62 \%, p$-value $=0.02)$ but not for large acquirors $(-9.73 \%, p$-value $=0.52)$.

Target Size. Similarly, relative target size has been associated with bidder returns, at least in the short-run. Alexandridis, Fuller, Terhaar, and Travlos (2013) find that the three-day bidder returns are $2.4 \%$ worse for large deals than for small deals. Spalt and Schneider 
(2016) find that target size is negatively related to three-day bidder announcement returns if the target is public, but positively related to three-day bidder announcement returns if the target is private. Here too, causal interpretation is complicated by the fact that acquirors of large firms may be different from acquirors of small firms. For instance, mature firms with declining profits may choose to acquire large firms while young growth firms may tend to acquire small firms. In our setting, both the winning and the losing bidders try to acquire the same firm, so there is no difference in absolute target size and there are only small differences in relative target size.

We calculate relative target size as the ratio of the transaction value (or the offered purchase price in the case of the losing bidder) and the bidder's market capitalization. Column (3) of Table $\mathrm{V}$ shows the effect of relative target size on long-run merger performance when acquirors are benchmarked against firms that bid for the same target. We find no difference in the merger effect for small and large targets. The merger effect for small targets is $-29.61 \%$ ( $p$-value: 0.01 ), and for large targets it is $-24.84 \%$ ( $p$-value: 0.30$)$.

Public vs. Private Targets. Prior large-sample studies show that announcement returns are significantly lower in acquisitions of publicly traded target firms than in acquisitions of privately owned ones (Betton, Eckbo, and Thorburn, 2008; Spalt and Schneider, 2016). Again, there is a selection issue when interpreting these results. Acquirors taking over public firms may differ in many aspects from firms that acquire private firms. In our setting, this selection problem is not present: Both winner and loser attempt to acquire the same firmeither both attempt to acquire a public firm or both attempt to acquire a private firm.

Column (4) of Table V confirms that acquisitions of public firms appear to destroy value. The merger effect is statistically insignificant and positive $(15.39 \%, p$-value: 0.59$)$ for acquisitions of private firms, but significantly negative $(-34.03 \%, p$-value: 0.00$)$ for acquisitions 
of public firms. ${ }^{14}$ The difference is economically large $(-34.03 \%)$ but fails to be significant at conventional levels ( $p$-value: 0.11$)$.

Diversification. Diversifying mergers are often suspected to generate little value, or even to be value-destroying. Early studies support this view (Morck, Shleifer, and Vishny, 1990), while more recent studies find either no significant effect of diversification on acquiror announcement returns (Spalt and Schneider, 2016) or even a positive effect (Akbulut and Matsusaka, 2010). Again, the problem with interpreting such results is that firms choose whether to acquire within or across industries. Firms that participate in diversifying mergers are different from firms engaging in concentrating acquisitions. In our sample, winners and losers of takeover contests are very similar in their tendency to diversify or concentrate.

We define an acquisition bid as diversifying if the bidder is in a Fama-French 12-industry classification that is different from that of the target (and as concentrating otherwise). In the full sample, the winner and loser in a contest have different diversification status (winner is diversifying, loser is concentrating or vice versa) in only 24 out of 112 contest. Moreover, in the subsample of close contests, diversification status between winners and losers differs in only eight out of 56 cases. Column (5) of Table V indicates that, on average, diversifying mergers appear to destroy value. The merger effect is $-21.64 \%$ ( $p$-value: 0.05 ) in concentrating mergers, and -48.24\% ( $p$-value: 0.14$)$ in diversifying mergers. However, the difference in the effect is not precisely estimated.

Number of Bidders. Another reason for poor merger outcomes could be overpayment due to bidding competition. A higher number of firms participating in the merger contest may induce more severe overbidding and thereby cause the winning bidder to experience worse post-merger performance. There is no clear evidence from prior large-sample studies that

\footnotetext{
14 Note that the direct effect of the public target dummy $\left(\alpha_{8}\right)$ is subsumed in the contest fixed effect. Hence the variable is not included in the regression.
} 
bidding competition decreases bidder returns (Moeller, Schlingemann, and Stulz, 2004; Spalt and Schneider, 2016), and there is even evidence to the contrary for earlier-stage bidding in private negotiations (Boone and Mulherin (2008)). We investigate the hypothesis in our sample, and also do not find such an effect. Column (6) shows that there is no difference in the estimated merger effect between contests with two and more than two bidders.

This result also alleviates the concern that our results of a negative average merger effect in close contests are exclusively driven by bidding competition in our specific sample. As the bidding competition becomes more intense the estimated effect does not appear to increase.

Hostile vs. Friendly. Another feature of the bidding process that could help to explain the post-merger underperformance of the acquiror is hostile bidding. Hostile bidders might bid higher than they would in a friendly takeover and end up exceeding the surplus generated by the merger. We note that there is no clear evidence of hostility-induced overbidding in existing large-sample studies (Betton, Eckbo, and Thorburn, 2008; Spalt and Schneider, 2016), but still investigate this possibility in our sample of contested bids.

The results are reported in column (7). We find that the merger effect for hostile bids is large and significant $(-131.00$ with a $p$-value of 0.05$)$. The difference to friendly bids is only somewhat smaller (-116.30) and still marginally significant ( $p$-value: 0.08$)$.

One caveat here is that the number of hostile bids in our sample is low. As the summary statistics in Table I.B reveal, hostile bids amount to less than one tenth of our Full Sample, and they are even less common in the subsample of close contests (ten out of 119 bids). One reason for this may be that hostile bids often induce targets to produce a white knight, and we exclude white knights from our sample due to their lack of comparability to other bidders. Thus, the explanatory power of this channel is somewhat limited. At the same time, we also note that the large estimated effect of hostility helps to explain interesting time variation in our results. The frequency of hostile bids declined drastically in the late 1980s. In our 
sample, we estimate a strongly negative merger effect for pre-2000 contests $(-54.67, p$-value: $0.00)$ and an insignificant effect for post-2000 contests (13.56, $p$-value: 0.38 ).

Acquisition premium. Another possible correlate of overpayment is a high acquisition premium. High premia should mechanically induce underperformance of the acquiror to the extent that the premium exceeds the target's stand-alone value plus the expected synergies from the merger. Empirically, though, it is difficult to measure the expected-synergies component and thus true overpayment. Our empirical analysis is therefore limited to the role of the acquisition premium, defined as the difference between offer price and stand-alone value of the target, without consideration of synergies.

We calculate the offer premium as the run-up in the target's stock price from 40 trading days prior to the beginning of the contest until one day after completion. Column (8) of Table V shows that we fail to estimate a significant effect. We note, though, that the merger effect for the subsample of large premia is significantly negative.

Form of Payment. Finally, we investigate whether the form of payment - cash, stock, or other-affects post-merger performance. Loughran and Vijh (1997) find that stock mergers exhibit poor long-run abnormal returns relative to size and market-to-book matched firms, while cash acquirors outperform the matched firms. ${ }^{15}$

Column (9) of Table V shows the estimated merger effect for all-cash offers versus those that use at least some stock. It is helpful for our analysis that the form of payment is very similar across winners and losers in our sample. The mean difference between winners and losers in the percentage of the transaction value offered in cash is only $0.49 \%$ in long-duration (close) contests. For comparison, it is $14.40 \%$ in short contests.

\footnotetext{
${ }^{15}$ For short-run announcement returns, the evidence is less clear. Betton, Eckbo, and Thorburn (2008) find only slightly higher announcement returns for cash bids than for stock bids, and Spalt and Schneider (2016) find more negative announcement returns for stock bids than cash bids only in the subsample of public targets.
} 
We find that, in the subset of deals that are partially financed with stock, the merger effect is small and marginally significant $(-20.45 \%, p$-value: 0.08$)$, while it is almost three times as large and statistically more significant for all-cash deals $(-56.46 \%, p$-value: 0.01$)$. The difference, however, fails to be significant at conventional levels ( $p$-value: 0.15 ).

This result is noteworthy since much of the previous literature focuses on the (seeming) underperformance of stock mergers. Our approach to identifying the merger effect reveals that, at least for the specific sample of contested mergers, the opposite is the case when acquirors are benchmarked against more comparable firms. Our finding builds on Shleifer and Vishny (2003) and Rhodes-Kropf and Viswanathan (2004) in that we question the notion of stock-merger underperformance; and we go beyond those prior studies in that we also point to cash-merger underperformance. This latter finding is consistent with the more negative view of cash deals that is commonly voiced among practitioners. Practitioners are often wary that, in deals settled in cash, the target simply seeks to cash out at the highest possible price, without long-term involvement and irrespective of the strategic fit of the merged entity. Under that scenario, many of these deals will result in poor long-run performance. By contrast, in deals settled in stock, the target has an economic interest in the subsequent performance of the merged company.

A complementary interpretation is proposed in the behavioral literature on mergers and acquisitions. As shown by Malmendier and Tate (2008), managers with overoptimistic expectations appear to engage in more merger transactions than their peers. Crucially, overconfidence induces more and lower-performing mergers only when the acquiror is cash-rich and can cash-finance the merger. As formalized and tested in Malmendier and Tate (2005) and Malmendier, Tate, and Yan (2011), overconfidence implies a difference in opinion about the value of the firm between the overconfident managers and outside capital-providers, inducing a reluctance to raise external financing and, in particular, stock financing. Both the 
practitioner view and the behavioral view are consistent with our finding that transactions performed at high cash prices appear to be drivers of the post-merger underperformance, as well as with the leverage results presented below.

Operating Performance. We also test to what extent low operating performance can explain the persistent post-merger divergence of winners' and losers' abnormal returns. We calculate operating cash flow similarly to Moeller, Schlingemann, and Stulz (2004) as net sales minus cost of goods sold and selling, general and administrative expenses, and express it as a percentage of total assets. ${ }^{16}$ Figure 5 shows the evolution of cash flows for winners and losers in long contests over the three years around the merger. We find that winner and loser cash flows track each other relatively closely, not only before but also after the contest. Moreover, we find the same pattern for a range of alternative measures of operating performance around mergers, following Healy, Palepu, and Ruback (1992). In all cases, there is no significant deviation of winner and loser trends post-merger. In other words, the observed stock underperformance does not reflect operating underperformance.

[Figure 5 approximately here]

Leverage. We now turn to the possibility that acquisitions impose a heavy burden for cashfinanced deals that rely on increasing debt obligations. In the case of cash deals, acquirors may have to draw down their cash holdings and take on additional debt in order to finance the deal. The increased net leverage may be viewed by the market as potentially harmful to the long-term health of the company. Penman, Richardson, and Tuna (2007), for example, find that leverage is negatively associated with future stock returns. A disregard of high

\footnotetext{
16 Moeller, Schlingemann, and Stulz (2004) further subtract the change in working capital to compute operating cash flow. We do not subtract this item as it is not available on a quarterly frequency, but we note that it represents only a small fraction of cash flows.
} 
leverage would also be consistent with both the practitioner view and the behavioral view on cash mergers outlined above.

We compare winners' and losers' net leverage ratios both before and after the merger. Using quarterly data, we compute net market leverage as the ratio of net debt (short-term plus long-term debt minus cash and short-term investments) to market value (total assets minus book equity plus market equity) of the firm. Alternatively, we use net book leverage and industry-adjusted net book or market leverage; all measures yield very similar results.

Figure 6 shows the evolution of net market leverage for winners and losers. The graph indicates that winners' net leverage ratios sharply increase from pre- to post-merger. In the pre-merger period, the winners' leverage ratio is declining, and winners have a somewhat lower leverage ratio than losers just before the merger. The merger brings about a sharp increase (from 12 to 20 percent) in the winners' leverage ratio while losers' leverage remains stable. This difference persists until three years after the merger.

Thus, while we do not have definitive evidence on the effect of capital structure changes, the correlational evidence points to the possibility that high leverage ratios necessary to finance and implement the merger might be constraining the acquiror post-merger.

[Figure 6 approximately here]

\section{Comparison with Existing Methodologies}

As a last step in our analysis, we use our findings to evaluate existing empirical approaches to estimating the returns to mergers. While our empirical approach to identification is limited to contested mergers and cannot easily be generalized, we can still apply existing approaches to our sample and compare the resulting estimates to our winner-loser estimates. Such an analysis allows us to assess possible biases in the existing approaches, at least to the extent 
that they materialize in our sample. We consider announcement returns, alpha estimates based on calendar-time portfolio regressions of winner-only portfolios, and winners' buyand-hold abnormal returns relative to the market portfolio. We present the corresponding estimates in Panel A of Table VI.

The first row of Panel A reports winners' three-day announcement returns. Announcement effects are commonly viewed as the most credible measure of the causal effect of mergers on acquiring-company stock returns, given the difficulty of identifying a valid benchmark for long-run performance. We find that the three-day announcement returns are negative but not statistically significant in closely contested mergers. Thus, compared to our winner-loser estimates, announcement effects underestimate the loss of value generated by mergers and the market is, on average, incorrect in its initial assessment of the causal effect of contested mergers.

[Table VI approximately here]

The second row of Panel A shows the winners' announcement returns around the date of the losers' withdrawal. We add these statistics since, compared to single-bidder acquisitions, the market may perceive the probability of deal success as lower at the announcement of the ultimate winner's initial bid, and therefore not react strongly at that point in time. When the losing bidder drops out of the contest, the takeover probablility for the winner increases and the market may react more strongly. In our sample, we do not find statistically or economically significant market reactions at the time of the losers' withdrawal.

In the third row, we report the losers' announcement returns around the date of their bid withdrawal. If the market views the acquisition as value-destroying, we expect a positive market reaction around the withdrawal date. We indeed find a strong, positive market reaction of $+1.8 \%$ in losers at the withdrawal of their bid. These results are consistent with 
the findings based on our winner-loser methodology, and they support the notion that losing bidders' performance is informative about the value created in mergers.

The fourth row shows four-factor abnormal returns of winners, using an equally-weighted calendar-time portfolio methodology for the contest period and post-acquisition returns of the winner. (The monthly alpha is scaled by the duration of the contest period and the three-year post-merger period so that the magnitude of the estimate is comparable to our long-run winner-loser estimates.) We estimate a positive and insignifcant alpha of $10.3 \%$, instead of a negative and significant effect as in the winner-loser method.

Finally, in row five, we calculate the long-run abnormal buy-and-hold returns of winners relative to the market portfolio. This is similar to our main estimates, which also use longrun BHARs, except that here the market return is used as a benchmark instead of the loser's performance. We find results that are quite different from the winner-loser approach. The winner-only effect is close to zero $(+0.1 \%$ on the Full Sample, and $+1.1 \%$ on the Contest Coverage Sample). To check the robustness of these winner-only estimates, we also compute long-run winner BHARs using alternative risk adjustments. We obtain -13.5 percent and -3.2 percent for industry-adjusted and risk-adjusted BHARs, respectively. Although they are also negative, these estimates are much smaller in magnitude than the corresponding winner-loser estimates, and none of them are statistically significant.

In summary, none of the traditional methods appear to capture the negative causal effect of mergers in our sample on average.

In Table VI, Panel B, we go one step further. Instead of simply comparing the respective overall estimates of the merger effect, we correlate the estimates case by case. Specifically, we regress the long-run winner-loser difference in BHARs on the three announcement returns calculated above and on the winner's long-run market-adjusted BHAR. ${ }^{17}$ This additional

\footnotetext{
17 We cannot regress our case-by-case winner-loser estimates on the winner's alpha, since alpha is a single
} 
analysis tests which of the traditional methods generates the same relative assessment of mergers, i.e., the same ordering of mergers with respect to the returns they produce, as our winner-loser methodology, even if the methodologies disagree on the absolute level of returns and possibly even on the sign of merger-induced abnormal returns.

For the winner's announcement return, we find an insignificantly negative correlation. In other words, in deals for which our estimates point to a more negative effect of mergers, the announcement effect tends to be more positive (less negative), while in deals for which our estimates point to a more positive (less negative) effect of mergers, the announcement effect tends to be more negative. Hence, the announcement effect fails to predict the causal effect of mergers even directionally.

The winner's three-day CAR at the loser's withdrawal, reported in the second row of Panel B, shows a positive correlation with our long-run winner-loser estimates, but it is not statistically significant. The loser's CAR around the withdrawal date, shown in the third row, has an even weaker correlation with our estimates.

Turning to the correlation with the winners' long-run BHARs, the picture is more encouraging. The correlation is positive and significant. Partly, this result may reflect the fact that the winners' long-run BHARs are part of the winner-loser difference in long-run BHARs. However, it is not entirely mechanical as the benchmarking against the loser can (and does) turn negative returns positive and vice versa. Quantitatively, the correlation amounts to about 65 percent, and the R-squared is about 40 percent.

Overall, these estimation results indicate that researchers should be cautious when using announcement returns to measure the expected returns to mergers. At least in the subsample of merger contests, the winner's announcement effect appears to be generally uninformative about the returns generated by the merger in the long-run. Existing methodologies focusing number. It is not estimated case by case. 
on long-run abnormal returns are better in terms of their relative assessment, but fail to capture the extent of value destruction (or creation) in our sample of mergers.

\section{Conclusion}

This paper makes two contributions. Methodologically, we exploit bidding contests to address the identification issue in estimating the returns to mergers. We argue that, in contests where at least two bidders have a significant ex-ante chance of winning, the post-merger performance of the losing bidder permits the calculation of the counterfactual performance of the winner without the merger. This logic applies to protracted merger fights, in which all participating bidders have, ex ante, a similar chance to win.

Substantively, this paper provides credible estimates of the effect of contested mergers on stock prices. We find that the stock returns of bidders in close contests are not significantly different before the merger contest, corroborating the validity of our methodology. Postmerger, however, bidder returns diverge significantly, providing us with the measure of a causal effect of mergers on acquiring-company stock. In the case of close contests, losers outperform winners by 24 to 37 percent over the three years following the merger. We also uncover an increase in the leverage of winners relative to losers after the merger. High payments for relatively large deals, especially payments in cash, appear to be the most important indicator of long-term underperformance, rather than other factors related to the productivity of the merged firm. These results draw attention to a commonly voiced practitioner concern about highly priced cash mergers, and are in contrast to the seeming underperformance of stock mergers emphasized in the academic literature. They are also consistent with the behavioral view that managers' overestimation of future returns are an important factor in explaining value-destroying merger activities.

In interpreting our results, it is important to keep two points in mind. First, while 
we argue that losers provide a good counterfactual for winners in long contests, we cannot rule out the presence of additional unobserved factors correlated with merger activity that affect abnormal returns. In the paper, we discuss possible omitted variables and show that the empirical evidence is generally inconsistent with the alternative explanations of our main result. Ultimately, though, the credibility of our estimates rests on the identification assumption, which of course cannot be tested directly.

Second, the external validity of our findings is unclear. Our estimates are based on contested mergers, which are not representative of the entire population of mergers. While a non-trivial fraction of mergers are contested (and the empirical assessment of merger contests is interesting in and of itself), the size and even the direction of the effect may not generalize to mergers more broadly. Indeed, our additional results linking acquiror underperformance to large cash transactions suggest that closely contested mergers maybe particularly likely to exhibiting long-term negative effects in the acquiring firm.

At the same time, the empirical estimates do allow us to evaluate existing methodologies at least in this specific context, which suggests caution in interpreting announcement effects as measures of the returns to mergers. Thus, despite the inherent difficulties in assessing long run abnormal returns, our results imply a renewed emphasis on developing long-term approaches along the lines of Lyon, Barber, and Tsai (1999), possibly coupled with matching on pre-merger stock returns. 


\section{References}

Akbulut, Mehmet E., and John G. Matsusaka, 2010, 50+ years of diversification announcements, The Financial Review 45, 231-262.

Alexandridis, George, Kathleen P. Fuller, Lars Terhaar, and Nickolaos G. Travlos, 2013, Deal size, acquisition premia and shareholder gains, Journal of Corporate Finance 20, 1-13.

Allen, Jason, Robert Clark, and Jean-Francois Houde, 2014, The effect of mergers in search markets: Evidence from the canadian mortgage industry, American Economic Review 104, 3365-3396.

Andrade, Gregor, Mark Mitchell, and Erik Stafford, 2001, New evidence and perspectives on mergers, Journal of Economic Perspectives 15, 103-120.

Asquith, Paul, Robert F. Bruner, and David W. Mullins Jr, 1987, Merger returns and the form of financing, Journal of Financial Economics 11, 121-139.

Betton, Sandra, B. Espen Eckbo, and Karin Thorburn, 2008, Corporate takeovers, in Handbook of Corporate Finance: Empirical Corporate Finance, volume 2, chapter 15 (North Holland/Elsevier).

Boone, Audra L., and J. Harold Mulherin, 2007, How are firms sold?, The Journal of Finance 62, 847-875.

- 2008, Do auctions induce a winner's curse? New evidence from the corporate takeover market, Journal of Finance Economics 89, 1-19.

Daniel, Kent, Mark Grinblatt, Sheridan Titman, and Russ Wermers, 1997, Measuring mutual fund performance with characteristic-based benchmarks, The Journal of Finance 52, 1035-1058.

Deneckere, Raymond, and Carl Davidson, 1984, Horizontal mergers and collusive behavior, The International Journal of Industrial Organization 2, 117-132.

Dimopoulos, Theodosios, and Stefano Sacchetto, 2014, Preemptive bidding, target resistance, and takeover premiums, Journal of Financial Economics 114, 444-470.

Gowrisankaran, Gautam, Aviv Nevo, and Robert Town, 2015, Mergers when prices are negotiated: Evidence from the hospital industry, American Economic Review 105, 172-203.

Greenstone, Michael, Richard Hornbeck, and Enrico Moretti, 2010, Identifying agglomeration spillovers: Evidence from winners and losers of large plant openings, Journal of Political Economy $118,536-598$.

Greenstone, Michael, and Enrico Moretti, 2004, Bidding for industrial plants: Does winning a 'million dollar plant' increase welfare?, Working Paper. 
Healy, Paul M., Krishna G. Palepu, and Richard S. Ruback, 1992, Does corporate performance improve after mergers?, Journal of Financial Economics 31, 135-175.

Ince, Ozgur S., and R. Burt Porter, 2006, Individual equity return data from Thomson Datastream: Handle with care!, Journal of Financial Research 29, 463-479.

Jensen, Michael C., 1986, Agency cost of free cash flow, corporate finance, and takeovers, American Economic Review Papers 83 Proceedings 76, 323-329.

- and Richard S. Ruback, 1983, The market for corporate control, Journal of Financial Economics 11, 5-50.

Loughran, Tim, and Anand M. Vijh, 1997, Do long-term shareholders benefit from corporate acquisitions?, Journal of Finance 52, 1765-1790.

Lyon, John D., Brad M. Barber, and Chih-Ling Tsai, 1999, Improved methods for tests of long-run abnormal stock returns, The Journal of Finance 54, 165-201.

Malmendier, Ulrike, and Geoffrey Tate, 2005, CEO overconfidence and corporate investment, The Journal of Finance 60, 2661-2700.

— , 2008, Who makes acquisitions? CEO overconfidence and the market's reaction, Journal of Financial Economics 89, 20-43.

— , and Jun Yan, 2011, Overconfidence and early-life experiences: The effect of managerial traits on corporate financial policies, Journal of Finance 66, 1687-1733.

Mitchell, Mark, Todd Pulvino, and Erik Stafford, 2004, Price pressure around mergers, Journal of Finance 59, 31-63.

Moeller, Sara B., Frederik P. Schlingemann, and René M. Stulz, 2004, Firm size and the gains from acquisitions, Journal of Financial Economics 73, 201-228.

—, 2005 , Wealth destruction on a massive scale? A study of acquiring-firm returns in the recent merger wave, Journal of Finance 60, 757-782.

Morck, Randall, Andrei Shleifer, and Robert Vishny, 1990, Do managerial objectives drive bad acquisitions?, The Journal of Finance 45, 31-48.

Penman, Stephen H., Scott Richardson, and Irem Tuna, 2007, The book-to-price effect in stock returns: Accounting for leverage, Journal of Accounting Research 45, 427-467.

Perry, Martin K., and Robert H. Porter, 1985, Oligopoly and the incentive for horizontal merger, The American Economic Review 75, 219-227.

Rau, Raghavendra, and Theo Vermaelen, 1998, Glamour, value, and the post-acquisition performance of acquiring firms, Journal of Financial Economics 49, 223-253. 
Rhodes-Kropf, Matthew, and S. Viswanathan, 2004, Market valuation and merger waves, The Journal of Finance 59, 2685-2718.

Richardson, Scott, Richard Sloan, and Haifeng You, 2011, What makes stock prices move? Fundamentals vs. investor recognition, Working Paper.

Roll, Richard, 1986, The hubris hypothesis of corporate takeovers, Journal of Business 59, 197-216.

Salant, Stephen W., Sheldon Switzer, and Robert J. Reynolds, 1983, Losses from horizontal merger: The effects of an exogenous change in industry structure on cournot-nash equilibrium, Quarterly Journal of Economics 98, 185-99.

Savor, Pavel G., and Qi Lu, 2009, Do stock mergers create value for aquirers?, The Journal of Finance 64, 10611097.

Shleifer, Andrei, and Robert W. Vishny, 2003, Stock market driven acquisitions, Journal of Financial Economics 70, 295-311.

Spalt, Oliver, and Christoph Schneider, 2016, Why does size matter so much for bidder announcement returns?, Working Paper.

Stigler, George J., 1950, Monopoly and oligopoly by merger, American Economic Review Papers \& Proceedings 40, 23-34.

Wermers, Russ, 2004, Is money really 'smart'? New evidence on the relation between mutual fund flows, manager behavior, and performance persistence, Working Paper, University of Maryland. 


\section{Figures and Tables}

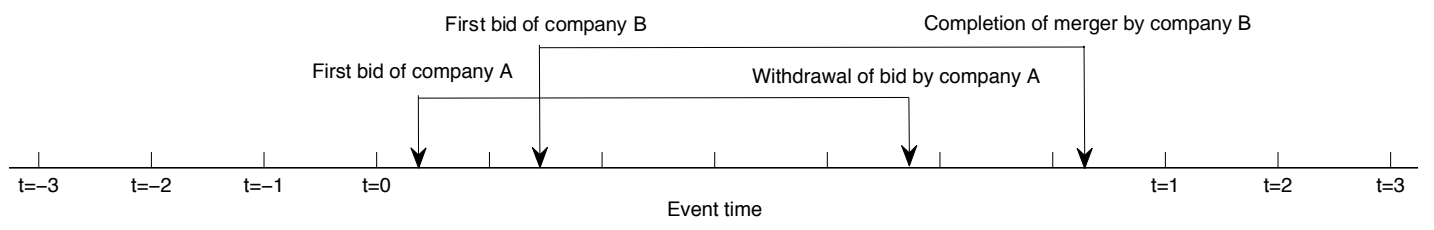

(a) Stylized Example

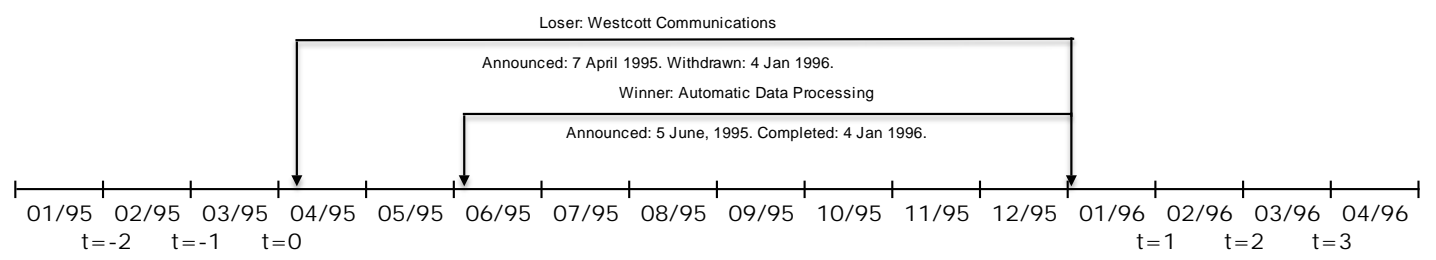

(b) Data Example

Figure 1

Construction of Event Time 


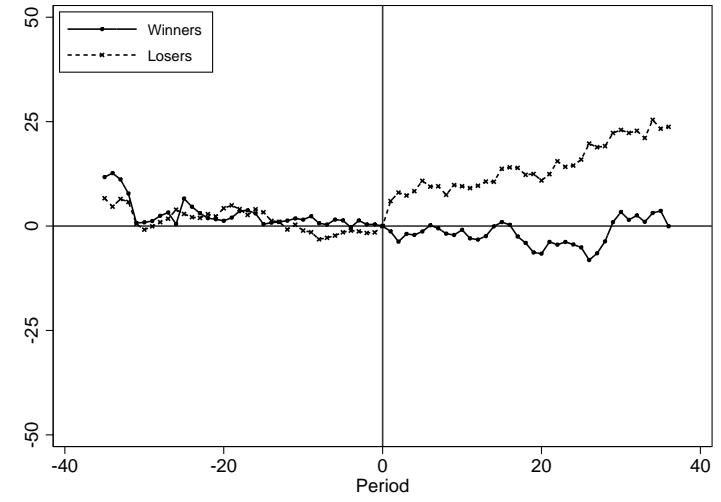

(a) Market-adjusted BHARs

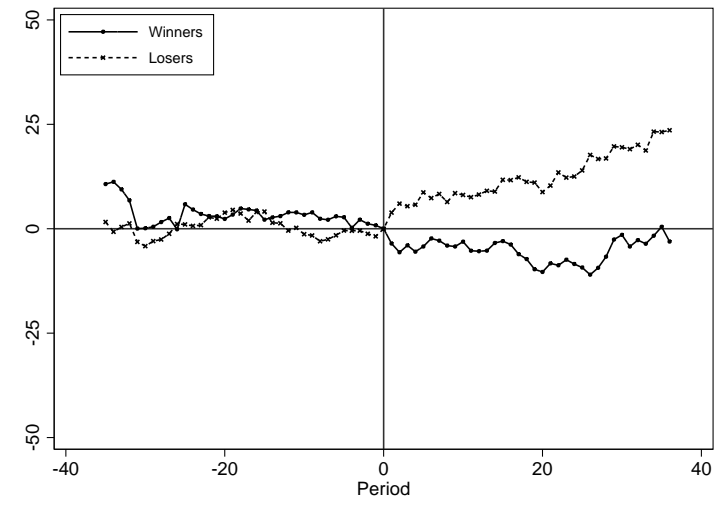

(c) Risk-adjusted BHARs

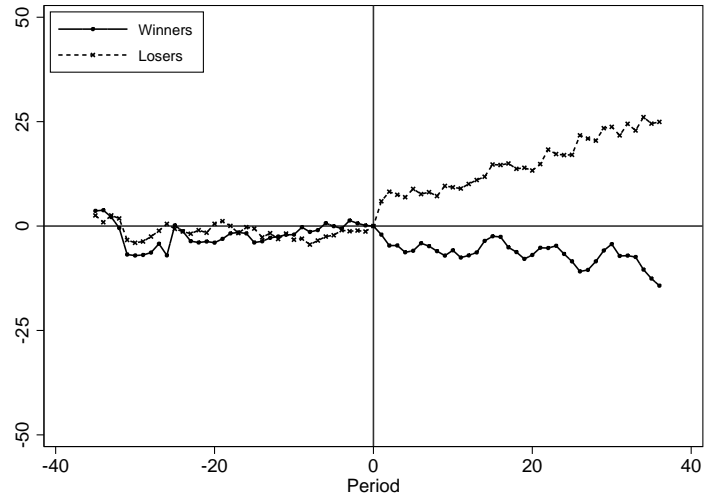

(b) Industry-adjusted BHARs

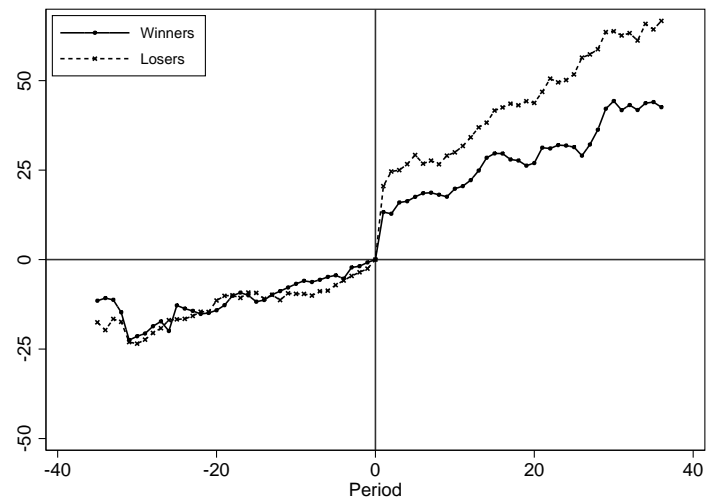

(d) Unadjusted buy-and-hold returns

Figure 2

Winner and Loser Performance

The graphs show the average stock price performance of winners and losers in close contests, i.e., in the long-duration subsample. The top graphs show market-adjusted and industry-adjusted buy-and-hold abnormal returns (BHARs). The bottom graphs show risk-adjusted BHARs and buy-and-hold raw returns. BHARs are calculated as described in Table III. Cumulative raw returns are calculated using the same formula, but setting the benchmark return to zero. The circles correspond to the average winner returns, the crosses to the average loser returns. 


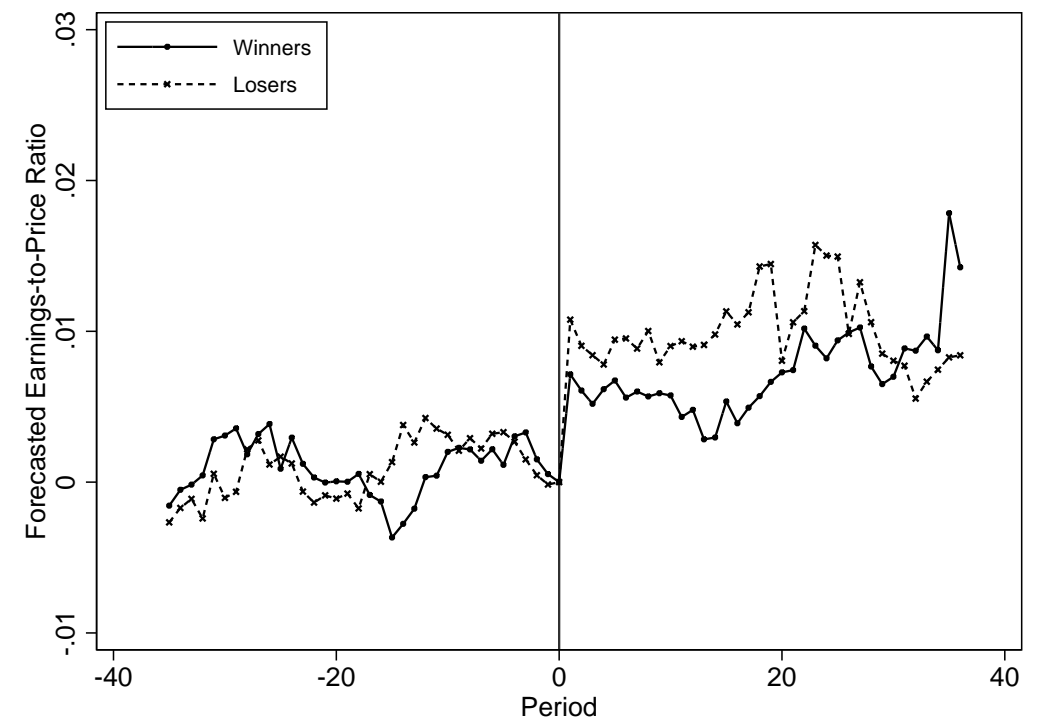

Figure 3

Forecasted Earnings-to-Price Ratio

The figure shows the forecasted earnings-to-price ratio $(F E / P$ ratio) of winners and losers around merger contests in long contests. The $F E / P$ ratio is computed as analysts' two-year consensus (mean) forecast divided by the stock price at the end of the forecast month. It is computed using quarterly data from I/B/E/S. The $F E / P$ ratio is normalized to zero in $t=0$ and expressed as a decimal. The circles correspond to the event-time specific mean $F E / P$ ratios of winners, the crosses to those of losers. 


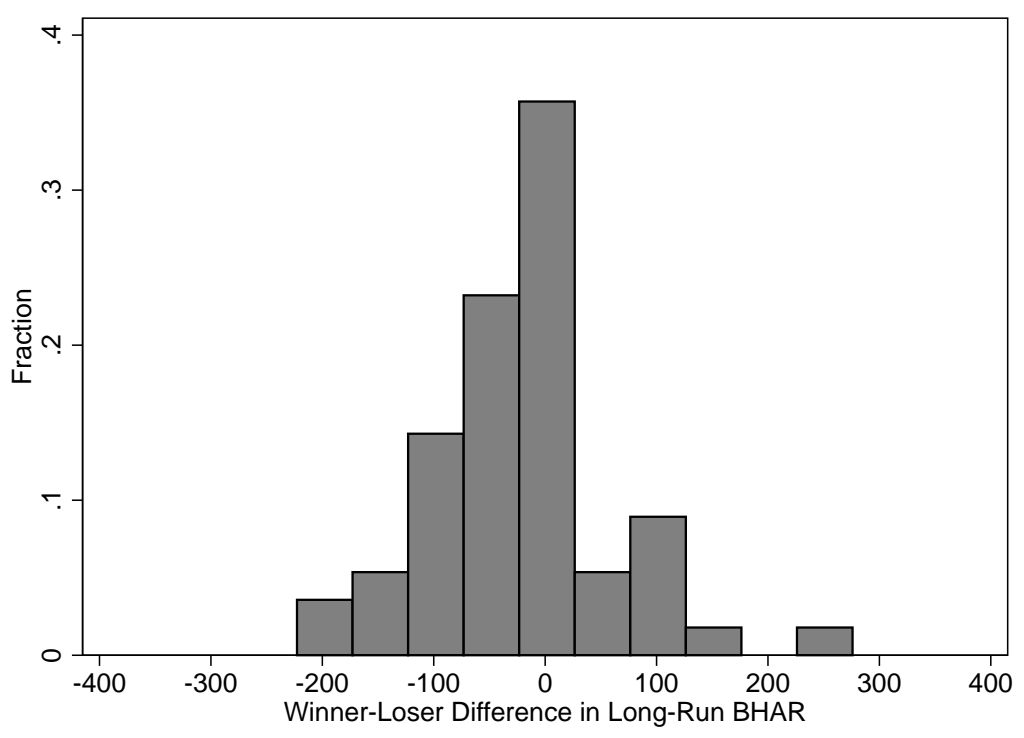

Figure 4

\section{Distribution of Merger Effect Estimates}

The histogram shows the distribution of the estimated merger effect for all 56 contests of above-median duration in our Full Sample. The merger effect is the winner-loser difference in the market-adjusted BHAR three years after the merger. 


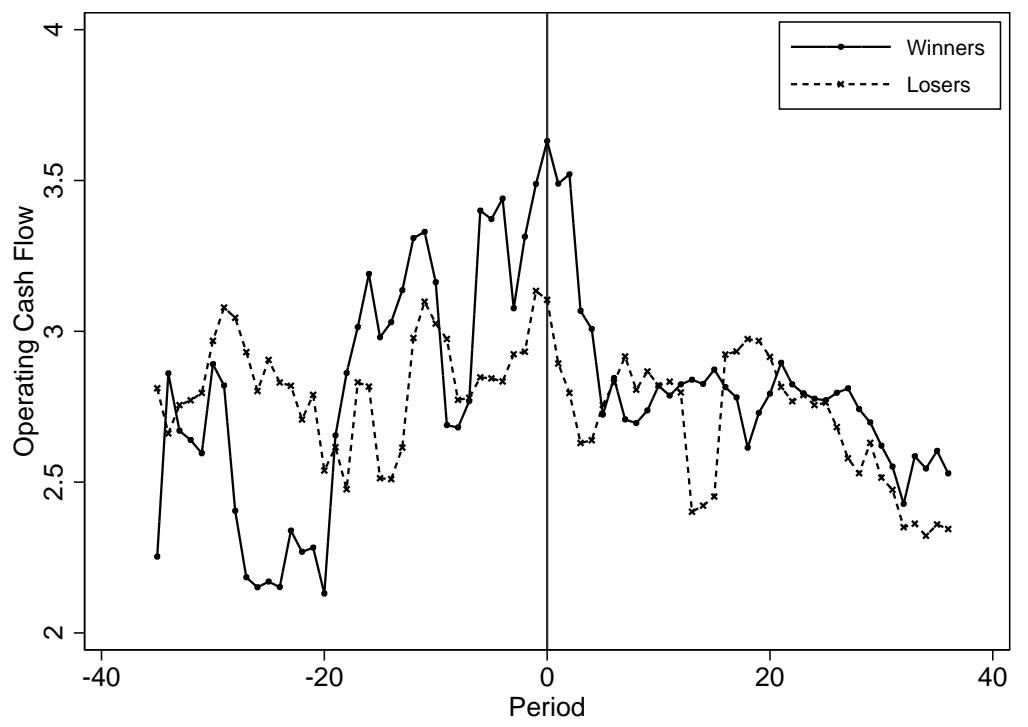

Figure 5

Operating Performance

The figure shows operating cash flow of winners and losers around merger contests in the subsample of long contests. Operating cash flow is calculated as the ratio of net sales minus cost of goods sold and selling, general and administrative expenses over total assets. It is based on quarterly data and is expressed as a percentage. The circles correspond to the event-time specific mean oeprating cash flow of winners, the crosses to those of losers. 


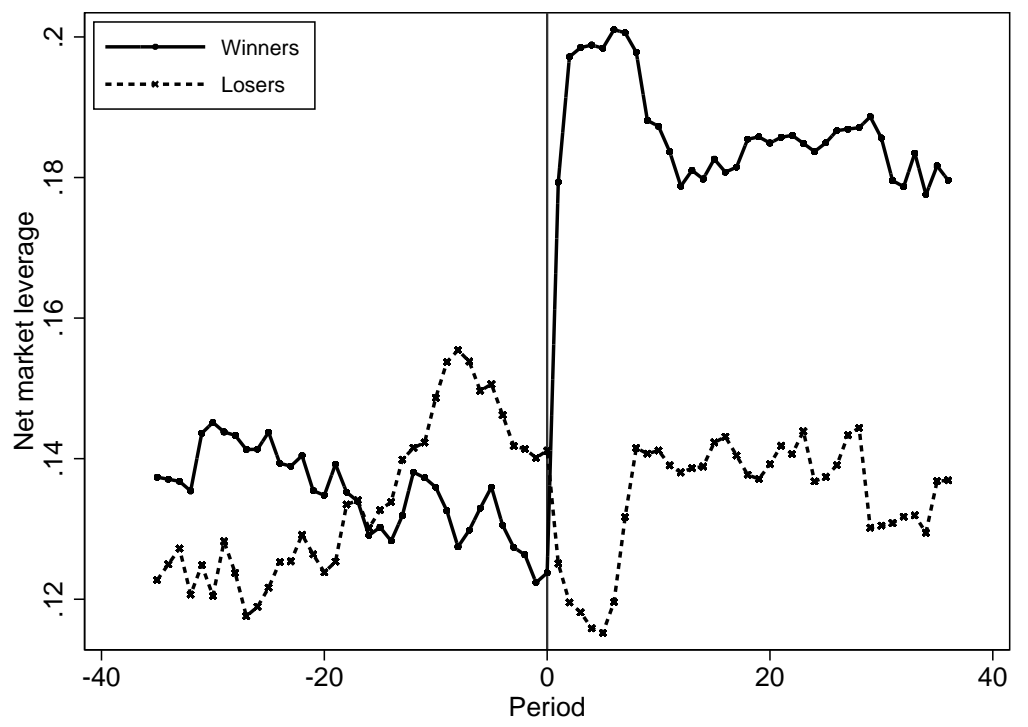

Figure 6

Net Market Leverage

The figure shows net market leverage of winners and losers around merger contests in long contests. Net market leverage is defined as debt in current liabilities plus long term debt minus cash and short-term investments, divided by total assets minus book equity plus market equity. The variable is computed using quarterly data. The circles correspond to the event-time specific mean leverage of winners, the crosses to those of losers. 


\section{Table I \\ Descriptive Statistics}

In Panel A, Total assets are the book value of total assets. Market value is Total assets plus market value of equity (common shares outstanding times fiscal-year closing price) minus book value of equity (book value of shareholders' equity, plus balance sheet deferred taxes and investment tax credit [if available], minus book value of preferred stock, where, depending on availability, we use redemption, liquidation, or par value (in that order) to estimate the book value of preferred stock). Tobin's Q is the ratio of Market value to book value of assets. PP\&E is book value of property, plant and equipment divided by total assets. Profitability is operating income before depreciation divided by total assets. Leverage is debt in current liabilities plus long term debt, either divided by Total assets (Book leverage) or by Market value (Market leverage). Announcement CAR [\%] is the three-day cumulative market-adjusted return around the announcement date of the winner's or loser's first bid in a given contest. Announcement CARs [\$m] are three-day cumulative dollar abnormal returns of the first bid, i.e., percentage announcement CARs multiplied by the bidder's pre-merger market value of equity. $p$-value of mean difference refers to the difference in means between winners and losers. In Panel B, Deal value is the dollar value of the winning bid. Tender offer is a dummy indicating a tender offer. Hostile is a dummy indicating whether the deal attitude of the winning bid was hostile. Percentage paid in stock is the percentage of the winning bid that is paid in stock. Percentage paid in cash is the percentage paid in cash. Number of bidders is the total number of bidders involved in the merger contest. Offer premium [\% of target] is the run-up in the target's stock price from 40 days prior to the announcement of the initial bid until completion of the merger contest. Offer premium [\% of acquiror] is Offer premium [\% of target] times target equity value divided by acquiror equity value. Contest duration is the number of months from the month-end preceding the first bid until the end of the month of the completion of the merger.

\begin{tabular}{|c|c|c|c|c|c|c|c|c|c|c|}
\hline \multicolumn{11}{|c|}{ Panel A: Bidder Characteristics } \\
\hline & \multicolumn{4}{|c|}{ Winners } & & \multicolumn{4}{|c|}{ Losers } & \multirow{2}{*}{$\begin{array}{l}p \text {-value of } \\
\text { mean diff. }\end{array}$} \\
\hline & Mean & Median & Std & $\mathrm{N}$ & & Mean & Median & Std & $\mathrm{N}$ & \\
\hline Total assets $[\$ \mathrm{~m}]$ & 12539.02 & 3063.65 & 26816.43 & 112 & & 7759.56 & 2527.63 & 12334.93 & 121 & 0.08 \\
\hline Market value $[\$ \mathrm{~m}]$ & 19152.86 & 5218.28 & 39326.26 & 112 & & 12153.98 & 3364.47 & 22549.19 & 121 & 0.10 \\
\hline Sales $[\$ \mathrm{~m}]$ & 6877.06 & 1680.42 & 16633.67 & 112 & & 4060.66 & 1172.70 & 8425.34 & 120 & 0.12 \\
\hline Tobin's Q & 1.88 & 1.41 & 1.36 & 112 & & 1.81 & 1.36 & 1.28 & 121 & 0.63 \\
\hline PP\&E & 0.29 & 0.22 & 0.25 & 109 & & 0.29 & 0.22 & 0.26 & 117 & 0.93 \\
\hline Profitability & 0.12 & 0.11 & 0.08 & 109 & & 0.13 & 0.12 & 0.11 & 117 & 0.72 \\
\hline Book leverage & 0.26 & 0.19 & 0.21 & 112 & & 0.23 & 0.19 & 0.18 & 117 & 0.18 \\
\hline Market leverage & 0.18 & 0.14 & 0.16 & 112 & & 0.17 & 0.14 & 0.15 & 117 & 0.61 \\
\hline Ann. CAR [\%] & -1.55 & -0.61 & 7.39 & 112 & & 0.00 & -0.01 & 0.07 & 120 & 0.25 \\
\hline Ann. CAR $[\$ \mathrm{~m}]$ & -333.56 & -6.95 & 1959.05 & 112 & & 12.43 & -4.94 & 877.99 & 119 & 0.08 \\
\hline \multicolumn{11}{|c|}{ Panel B: Deal Characteristics } \\
\hline & & & $\mathrm{P} 25$ & Median & P75 & Mean & Std & $\mathrm{N}$ & & \\
\hline Deal value $[\$ \mathrm{~m}]$ & & & 88.32 & 484.48 & 1,186 & $2,989.48$ & $10,760.02$ & 110 & & \\
\hline Tender offer & & & 0.00 & 0.00 & 0.00 & 0.00 & 0.00 & 112 & & \\
\hline Hostile & & & 0.00 & 0.00 & 0.00 & 0.09 & 0.29 & 112 & & \\
\hline Percentage paid in & tock & & 0.00 & 0.00 & 68.44 & 30.92 & 40.67 & 112 & & \\
\hline Percentage paid in & ash & & 0.00 & 39.41 & 100.00 & 47.19 & 45.04 & 112 & & \\
\hline Number of bidders & & & 2.00 & 2.00 & 3.00 & 2.38 & 0.89 & 112 & & \\
\hline Offer premium [\% & target] & & 31.49 & 51.78 & 79.35 & 63.47 & 62.87 & 80 & & \\
\hline Offer premium $[\%$ & acquiror] & & 1.68 & 5.99 & 18.14 & 10.00 & 20.43 & 80 & & \\
\hline Contest duration $[\mathrm{r}$ & onths] & & 4.00 & 7.00 & 10.00 & 8.59 & 6.66 & 112 & & \\
\hline
\end{tabular}




\section{Table II}

\section{Winner-Loser Similarities: Correlation in Pre-Merger Abnormal Returns}

Winner-loser similarities in abnormal returns are estimated in two steps: In the first step (unreported), we estimate market-adjusted abnormal performance trends for each bidder by regressing each bidder's market-adjusted returns on a constant, separately for the three-year pre-merger and the three-year postmerger periods. In the second step, we regress the abnormal performance trends of the winners on those of the losers in the same merger contest and in the same (pre- or post-merger) period. The table reports the resulting coefficients of this univariate regression, separately for the different samples (Panel A to C). We show the pre-merger period results split up into above-median and below-median subsamples of contest duration (column 1 and 2) as well as the full sample (column 3) for the pre-merger period. For completeness, the last column also shows the result for the post-merger period. The intercept is omitted.

\begin{tabular}{|c|c|c|c|c|}
\hline \multicolumn{5}{|c|}{ Panel A: Full Sample } \\
\hline & \multicolumn{2}{|c|}{ Pre-merger } & \multirow{2}{*}{$\begin{array}{l}\text { Pre-merger } \\
\text { Full sample }\end{array}$} & \multirow{2}{*}{$\begin{array}{l}\text { Post-merger } \\
\text { Full sample }\end{array}$} \\
\hline & Long & Short & & \\
\hline Coefficient & $0.586^{* * *}$ & $0.272^{* *}$ & $0.369^{* * *}$ & $0.308^{* * *}$ \\
\hline & $(0.186)$ & $(0.104)$ & $(0.096)$ & $(0.090)$ \\
\hline R-squared & 0.16 & 0.11 & 0.12 & 0.10 \\
\hline Observations & 56 & 56 & 112 & 112 \\
\hline \multicolumn{5}{|c|}{ Panel B: Contest Coverage Sample } \\
\hline & \multicolumn{2}{|c|}{ Pre-merger } & Pre-merger & Post-merger \\
\hline & Long & Short & Full sample & Full sample \\
\hline Coefficient & $0.645^{* *}$ & $0.239^{* *}$ & $0.343^{* * *}$ & 0.175 \\
\hline $\mathrm{SE}$ & $(0.249)$ & (0.119) & $(0.116)$ & $(0.112)$ \\
\hline R-squared & 0.14 & 0.09 & 0.09 & 0.03 \\
\hline Observations & 43 & 44 & 87 & 87 \\
\hline \multicolumn{5}{|c|}{ Panel C: International Sample } \\
\hline & \multicolumn{2}{|c|}{ Pre-merger } & Pre-merger & Post-merger \\
\hline & Long & Short & Full sample & Full sample \\
\hline Coefficient & $0.307^{* *}$ & $0.289^{* * *}$ & $0.296^{* * *}$ & $0.247^{* * *}$ \\
\hline $\mathrm{SE}$ & $(0.136)$ & $(0.081)$ & $(0.075)$ & $(0.064)$ \\
\hline R-squared & 0.05 & 0.12 & 0.08 & 0.08 \\
\hline Observations & 92 & 92 & 184 & 184 \\
\hline
\end{tabular}




\section{Table III}

\section{Winner-Loser Differences in Long-Run Abnormal Returns}

The regression equation in all columns is: $B H A R_{i j t}=\alpha_{0}+\alpha_{1} W_{i j t}+\alpha_{2} t_{i j t}+\alpha_{3} t_{i j t} \cdot W_{i j t}+\alpha_{4}$ Post $_{i j t}+$ $\alpha_{5}$ Post $_{i j t} \cdot W_{i j t}+\alpha_{6} t_{i j t} \cdot$ Post $_{i j t}+\alpha_{7} t_{i j t} \cdot$ Post $_{i j t} \cdot W_{i j t}+\eta_{j}+\varepsilon_{i j t}$ (equation (3)). The regressions are run on the subsample of long (above-median) contest duration of the sample indicated in the first row. The dependent variable is the market-adjusted buy-and-hold abnormal return, normalized to zero in the month preceding the start of the contest and computed as $B H A R_{i j t}=\prod_{s=1}^{t}\left(1+r_{i j s}\right)-\prod_{s=1}^{t}\left(1+r_{s}^{m k t}\right)$ going forward in event time, and as $B H A R_{i j t}=\prod_{s=0}^{t+1}\left(1+r_{i j s}\right)^{-1}-\prod_{s=0}^{t+1}\left(1+r_{s}^{m k t}\right)^{-1}$ going backward, where $i$ denotes the bidder, $j$ the contest and $t$ the event month. The market return is the CRSP value-weighted market return. Winner $\left(W_{i j t}\right)$ is a dummy indicating whether bidder $i$ is a winner in merger contest $j . t$ is a variable counting event time. The dummy variable Post $_{i j t}$ indicates whether period $t$ is in the post-merger window of contest $j$. The lower part of the table between the two solid lines reports tests for the long-run winner-loser differences in BHARs at $t=+36$. Standard errors (in parentheses) are clustered by contest.

\begin{tabular}{|c|c|c|c|}
\hline Sample: & $\begin{array}{l}\text { Full Sample } \\
\text { (1) }\end{array}$ & $\begin{array}{c}\text { Contest Coverage } \\
(2)\end{array}$ & $\begin{array}{l}\text { Intl. Sample } \\
\text { (3) }\end{array}$ \\
\hline Winner $\left(\alpha_{1}\right)$ & $\begin{array}{c}1.049 \\
(3.963)\end{array}$ & $\begin{array}{l}-0.237 \\
(5.186)\end{array}$ & $\begin{array}{l}-0.008 \\
(2.520)\end{array}$ \\
\hline $\mathrm{t}\left(\alpha_{2}\right)$ & $\begin{array}{l}-0.182 \\
(0.217)\end{array}$ & $\begin{array}{l}-0.190 \\
(0.272)\end{array}$ & $\begin{array}{l}0.111 \\
(0.137)\end{array}$ \\
\hline Winner $\times \mathrm{t}\left(\alpha_{3}\right)$ & $\begin{array}{l}-0.018 \\
(0.245)\end{array}$ & $\begin{array}{l}-0.236 \\
(0.294)\end{array}$ & $\begin{array}{c}0.011 \\
(0.178)\end{array}$ \\
\hline Post $\left(\alpha_{4}\right)$ & $\begin{array}{l}6.756 \\
(8.130)\end{array}$ & $\begin{array}{l}3.720 \\
(9.075)\end{array}$ & $\begin{array}{l}5.382 \\
(5.837)\end{array}$ \\
\hline Winner $\times$ Post $\left(\alpha_{5}\right)$ & $\begin{array}{l}-8.927 \\
(7.768)\end{array}$ & $\begin{array}{l}-7.239 \\
(10.00)\end{array}$ & $\begin{array}{l}-4.472 \\
(5.622)\end{array}$ \\
\hline $\mathrm{t} \times \operatorname{Post}\left(\alpha_{6}\right)$ & $\begin{array}{l}0.693^{*} \\
(0.367)\end{array}$ & $\begin{array}{r}0.978^{* *} \\
(0.438)\end{array}$ & $\begin{array}{l}-0.043 \\
(0.233)\end{array}$ \\
\hline Winner $\times$ Post $\times \mathrm{t}\left(\alpha_{7}\right)$ & $\begin{array}{l}-0.433 \\
(0.423)\end{array}$ & $\begin{array}{l}-0.563 \\
(0.535)\end{array}$ & $\begin{array}{l}-0.273 \\
(0.241)\end{array}$ \\
\hline Contest fixed effects & Yes & Yes & Yes \\
\hline $\begin{array}{l}\text { Merger effect at } t=36 \\
\text { Merger effect: } p \text {-value }\end{array}$ & $\begin{array}{l}-23.69^{* *} \\
0.03\end{array}$ & $\begin{array}{c}-35.46^{* * *} \\
0.01\end{array}$ & $\begin{array}{l}-13.63^{* *} \\
0.05\end{array}$ \\
\hline $\begin{array}{l}\text { Observations } \\
\text { R-squared } \\
\text { Number of contests }\end{array}$ & $\begin{array}{c}8,568 \\
0.28 \\
56\end{array}$ & $\begin{array}{c}6,408 \\
0.26 \\
43\end{array}$ & $\begin{array}{c}14,040 \\
0.28 \\
92\end{array}$ \\
\hline
\end{tabular}




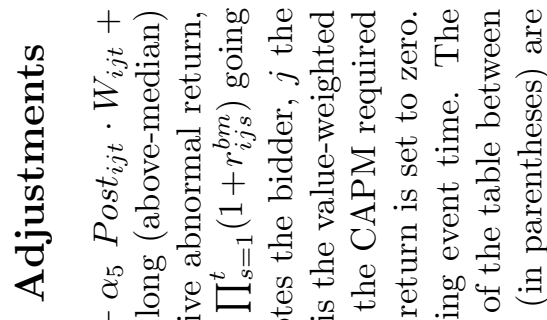

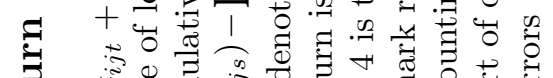

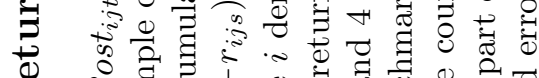

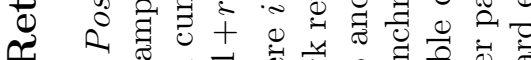

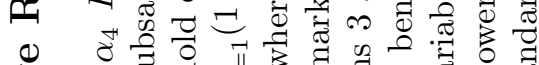

$>\quad+\quad$ के

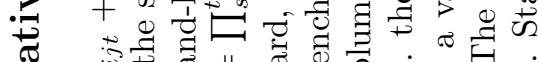

至

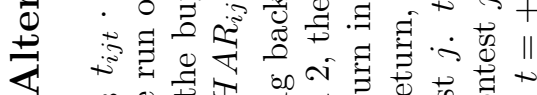
ơ

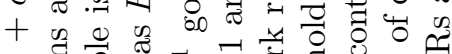

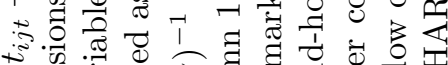

Q

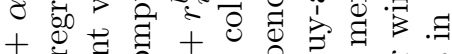

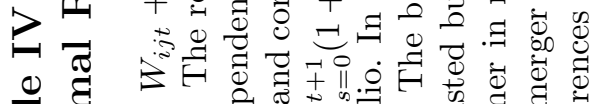

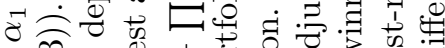

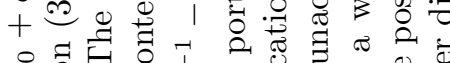

\&.

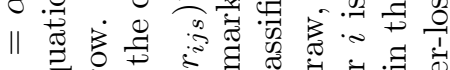

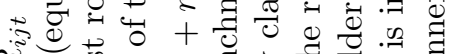

开

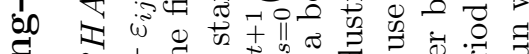

oี $\begin{gathered}0 \\ 0\end{gathered}$

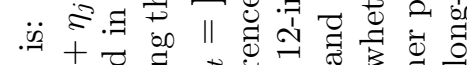

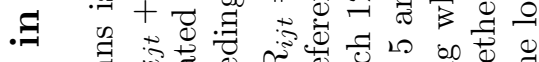

a

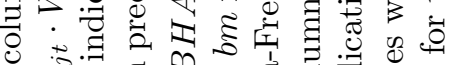
ส

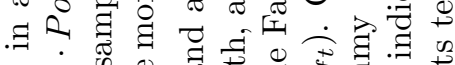
范范势

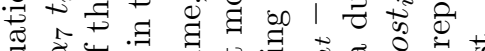

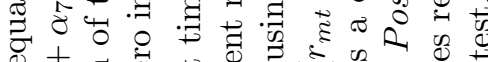

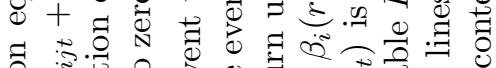

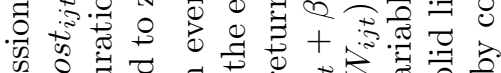

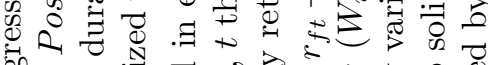

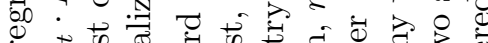

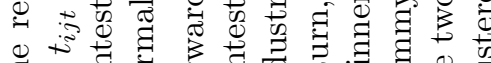

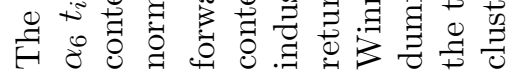

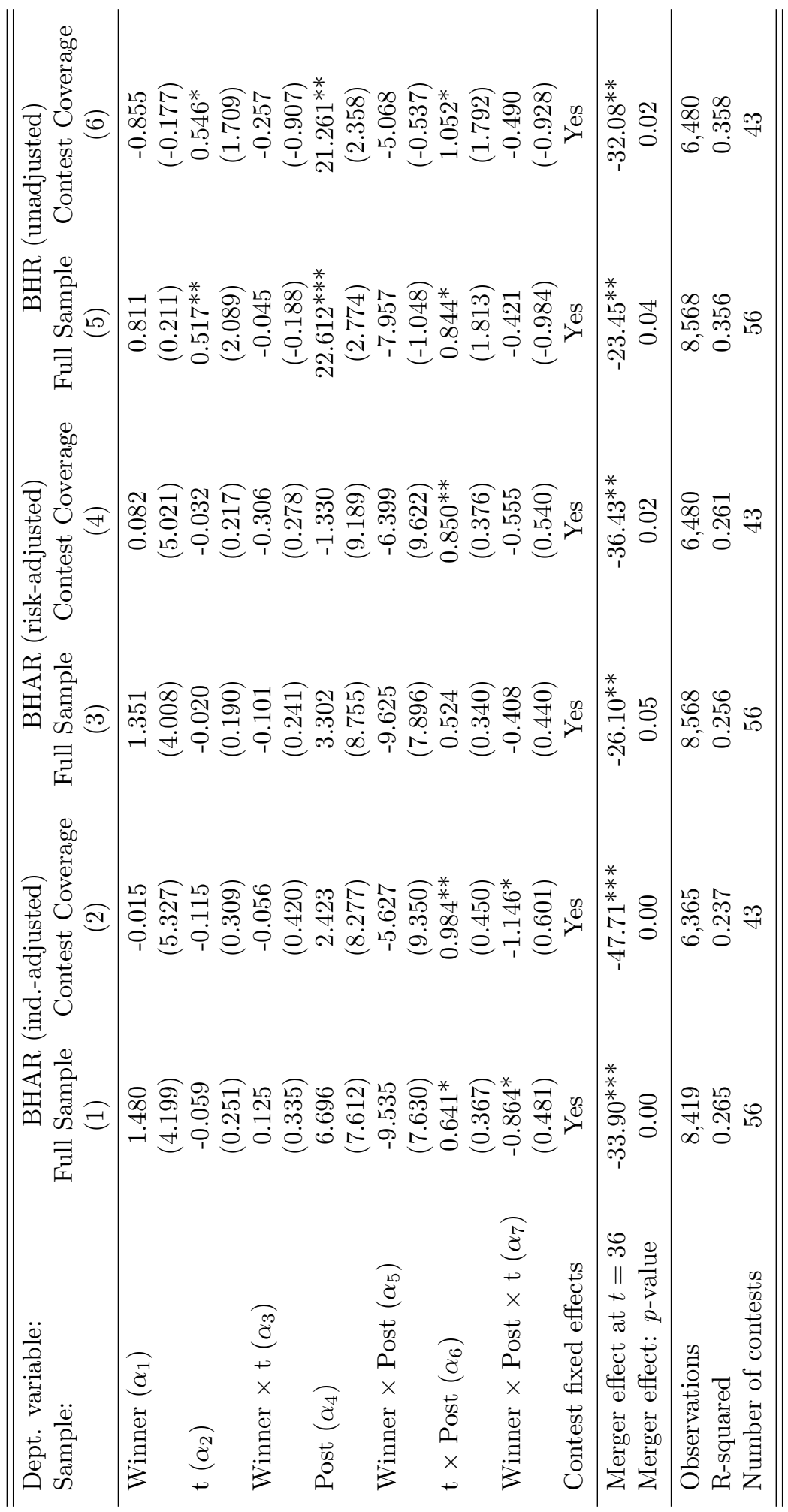




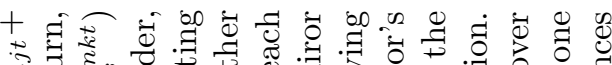

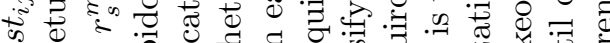

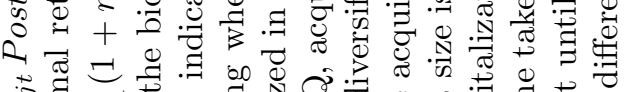

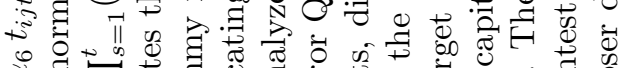

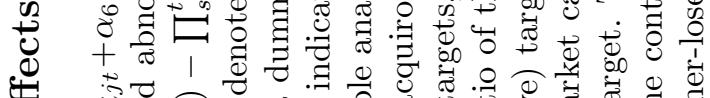

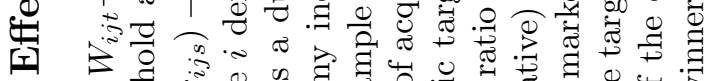

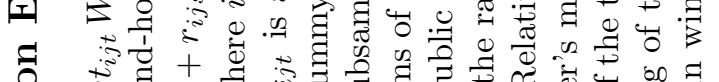

苟

\%

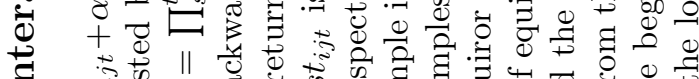

马

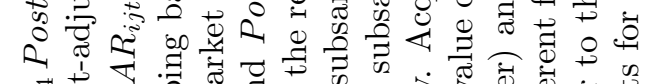

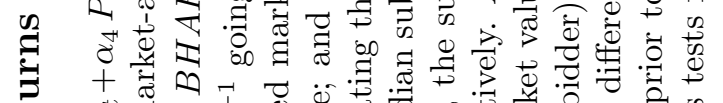

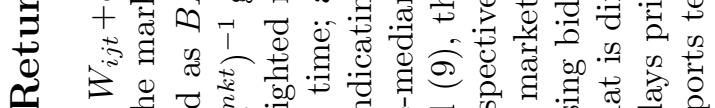

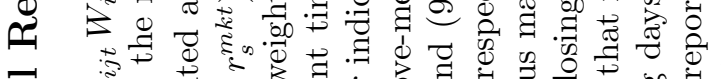

ส

I

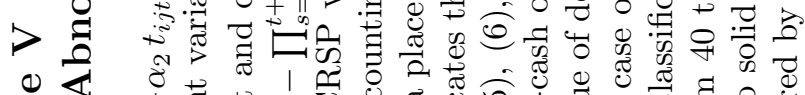

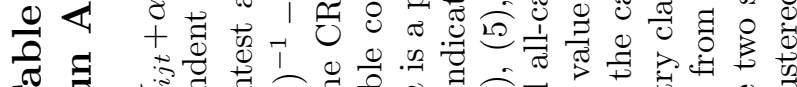

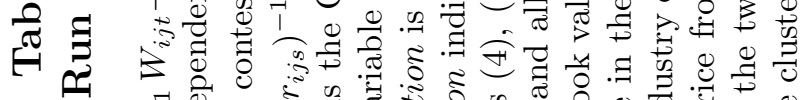

b $\quad \begin{aligned} & 0 \\ & 0\end{aligned}$

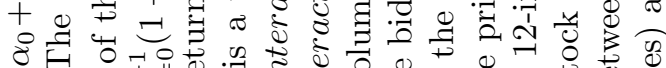
II.

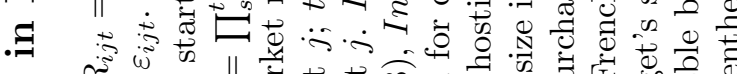

क

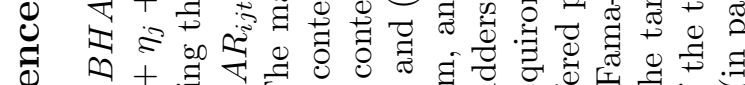

可

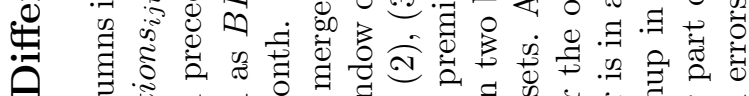

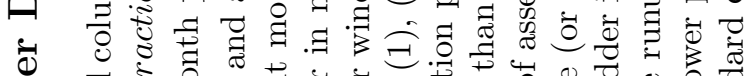

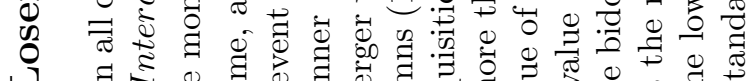

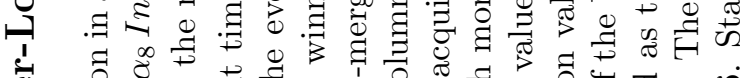

过

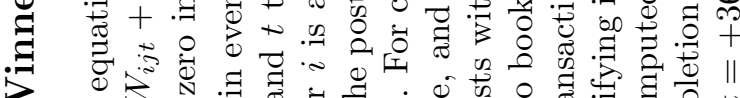

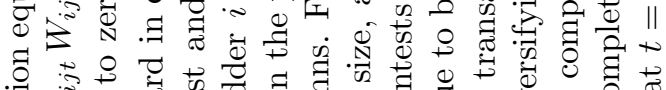

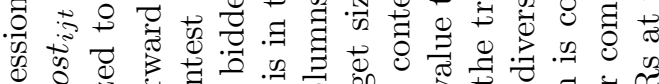

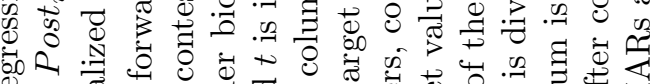

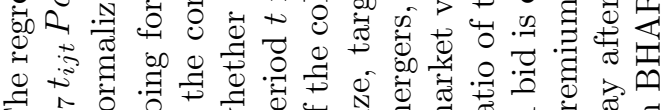

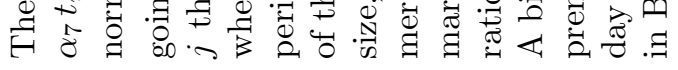

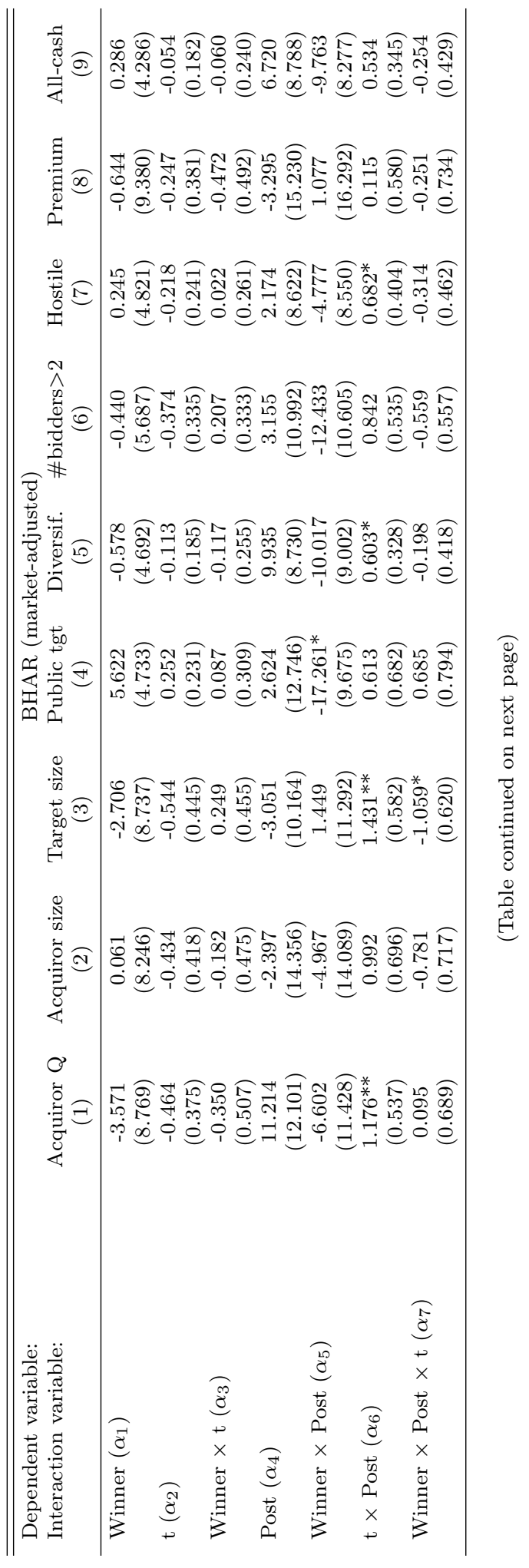




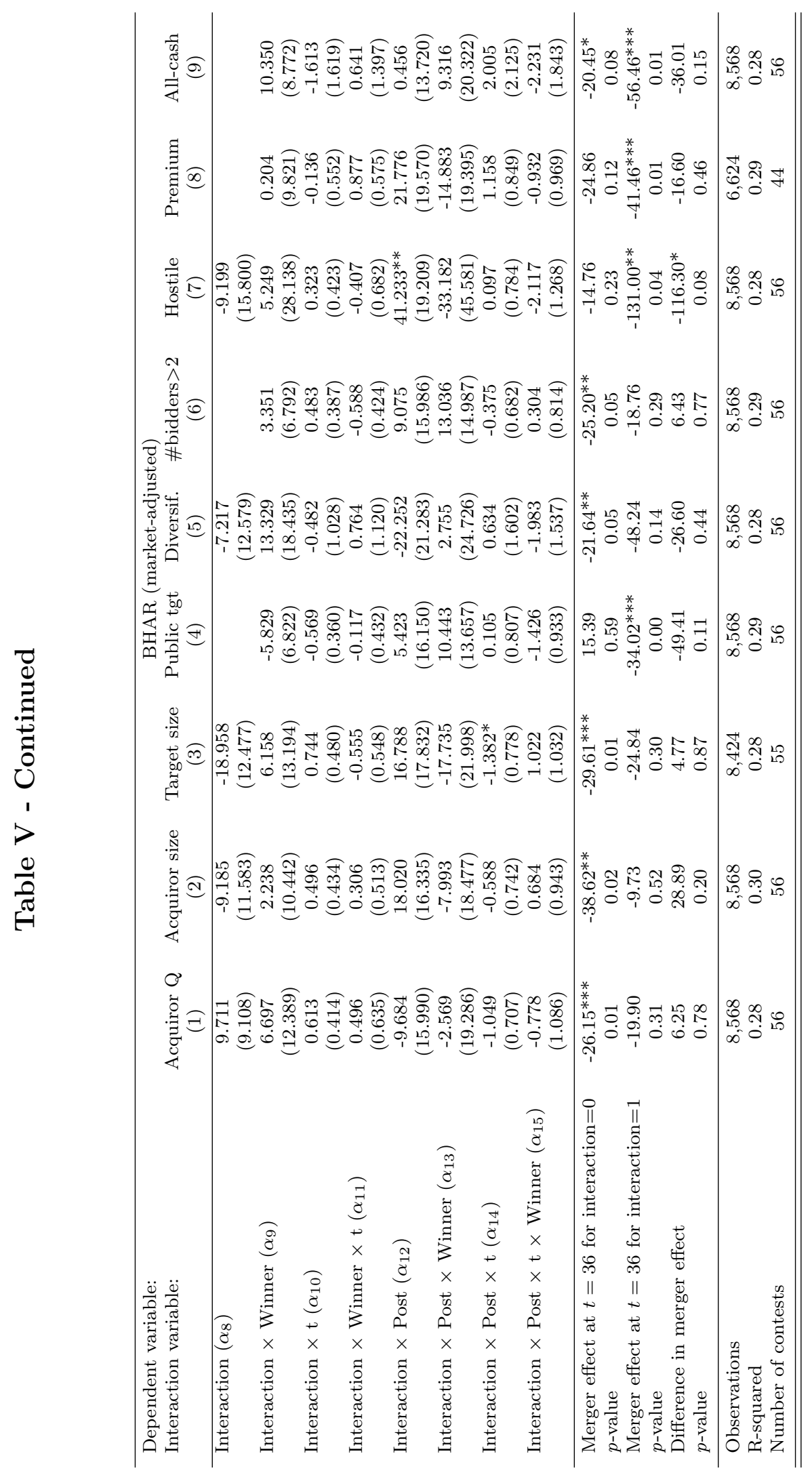




\section{Table VI}

\section{Alternative Methods to Assess the Returns to Mergers - Comparison}

Panel A reports the three-day market-adjusted return to the aquiror at announcement of the acquiror's initial bid (first row) and at the announcement of the loser's withdrawal (second row), the return to the loser at withdrawal (third row), the four-factor alpha of equally-weighted calendar-month portfolios of post-acquisition acquiror returns (fourth row), and the long-run buy-and-hold market-adjusted return of acquirors (fifth row). The four-factor alpha is the intercept of a time-series regression of the equally weighted excess return of an acquiror portfolio on the excess market return, the Fama-French factors, and the momentum factor. We use all acquiror stock returns that occur during the contest period or the following 36 months. The four-factor alpha from the monthly return regression is multiplied by 36 plus the average contest duration to make it comparable to the performance measurement period used for the estimates in Table III. Panel B reports univariate regressions of the long-run winner-loser difference in BHARs on the return at announcement of the acquiror's initial bid (first row) and at the announcement of the loser's withdrawal (second row), the return to the loser at withdrawal (third row), and the long-run buy-and-hold market-adjusted return of acquirors (last row). Standard errors are in parentheses.

\begin{tabular}{lccc}
\hline \hline \multicolumn{4}{c}{ Panel A: Estimates from traditional methods } \\
\hline \\
Winners' announcement CAR [\%] & -1.097 & $(0.799)$ & 56 \\
Winners' CAR at loser's withdrawal [\%] & -0.095 & $(0.824)$ & 55 \\
Losers' CAR at loser's withdrawal [\%] & $1.798^{* *}$ & $(0.715)$ & 62 \\
Winners' 4-factor alpha $\times$ (36+avg contest duration) & 10.335 & $(10.467)$ & 56 \\
Winners' market-adjusted BHAR [\%] & 0.097 & $(13.315)$ & 56 \\
\hline \multicolumn{1}{c}{ Panel B: Correlation with estimates from traditional methods } & \\
\hline & Coefficient & SE & $\mathrm{N}$ \\
\cline { 2 - 4 } Winners' announcement CAR [\%] & -3.496 & $(2.288)$ & 56 \\
Winners' CAR at loser's withdrawal [\%] & 3.821 & $(2.262)$ & 56 \\
Losers' CAR at loser's withdrawal [\%] & 0.504 & $(2.243)$ & 62 \\
Winners' market-adjusted BHAR [\%] & $0.649^{* * *}$ & $(0.108)$ & 56 \\
\hline \hline
\end{tabular}




\section{Appendix: Sample Construction}

In this Appendix, we provide more details on the construction of our data set from Thomson One Mergers and Acquisitions, CRSP, Compustat, Compustat Global, Datastream, and $\mathrm{I} / \mathrm{B} / \mathrm{E} / \mathrm{S}$.

The initial data collection from Thomson One for the two North American samples described in the main paper includes the following variables: deal number of each bid, acquiror's and target's company identifiers (CIDGEN), six-digit CUSIP, nation, SIC code, announcement date of the bid, its effective or withdrawal date, dollar value of the offer, percentage of the transaction value offered in cash, in stock, or in other means of payment, deal attitude (friendly or hostile), number of bidders involved in the bidding process, and competing bid flag. We collect those data items for the period from 1/1/1985 to 12/31/2012.

We collect the following data for the longer period (including +/- three years) of 1/1/1982 to 12/31/2015: From the CRSP Monthly Stock Database, we obtain holding period stock return (RET), distribution event code (DISTCD), delisting code (DLSTCD), date of delisting payment (DLPDT), amount after delisting (DLAMT), delisting return (DLRET), and CRSP value-weighted index returns (VWRETD). From the Fama-French data library, we obtain the monthly Fama-French factor returns (MKTRF, SMB, HML), the risk-free rate, and value-weighted industry returns (12-industry classification). From the CRSP-COMPUSTAT Fundamentals Annual Database we obtain yearly accounting data, including total assets (AT), net sales (SALE), total debt (LT), shareholders' equity (SEQ), deferred taxes and investment tax credit (TXDITC), preferres stock liquidating, redemption and carrying value (PSTKL, PSTKRV, UPSTK, respectively), common shares outstanding (CSHO), fiscal year closing price (PRCC_F), and operating income (OIBDP). From the CRSP-COMPUSTAT Fundamentals Quarterly Database, we obtain quarterly data on total assets (ATQ), debt in current liabilities (DLCQ), long-term debt (DLTTQ), cash and short-term investments 
(CHEQ), common shares outstanding (CSHOQ), fiscal quarter closing price (PRCCQ), book value of shareholders' equity (SEQQ), balance sheet deferred taxes and investment tax credit (TXDITCQ), book value of preferred stock (PSTKQ), net sales (SALEQ), cost of goods sold (COGSQ), and selling, general and administrative expenses (XSGAQ). We use the CRSPCOMPUSTAT quarterly data to construct the time series of operating cash flow and various measures of leverage (book and market leverage, as well as net book and net market leverage) for each bidder.

We merge the Thomson One and CRSP data using the 6-digit CUSIPs. Specifically, we match the 6-digit CUSIP provided by Thomson One with the first six digits of CRSP's historical CUSIP (NCUSIP). Since the CUSIP of a firm can change over time, and reassignment of CUSIPs is particularly common following a merger, we match Thomson One's bidder CUSIP with CRSP's NCUSIP for the month preceding the announcement of the bid. We manually check that the company names recorded by Thomson correspond to the matched CRSP company names. If a firm has multiple equity securities outstanding, we use (1) the common stock if common and other types of stock are traded; (2) Class A shares if the company has Class A and Class B outstanding; and (3) the stock with the longest available time series of data if there are multiple types of common stock traded.

We use the stock return data to construct the monthly time series of bidder returns for a window of $+/-$ three years around the merger contest (from event time $t=-35$ to event time $t=+36)$. Depending on the duration of the bidding contest, the length of the return time series vary. The CRSP holding period return is adjusted for stock splits, exchanges, and cash distributions. (This adjustment is important since these events are particularly common around mergers.) We then construct the corresponding time series of CRSP valueweighted market returns and of value-weighted industry returns. From these return series we construct buy-and-hold abnormal returns as described in Section II. 
For publicly listed target firms, we also construct time series of daily returns to calculate the offer premium, computed as the percentage run-up in stock price from 40 trading days prior to the beginning of the contest until the day of delisting. Alternatively, we express the offer premium as a percentage of the acquirors' equity value (percentage run-up in the target stock price $\times$ target market capitalization / acquiror market capitalization).

In the three-year period after a merger, many bidders disappear from CRSP due to delisting. To reduce survivorship bias, we calculate the return implications of the delisting events for shareholders using all delisting information available in CRSP. The delisting code (DLSTCD) classifies delistings into mergers, exchanges for other stock, liquidations, and several other categories of dropped firms; the distribution information (DIVAMT) reports to what extent shareholders were paid in cash or stock; and the delisting return (DLRET) provides the shareholder returns from the last day the stock was traded to the earliest post-delisting date for which CRSP could ascertain the stock's value. We round the delisting return period to full months and track the performance of a delisted firm from the perspective of a buyand-hold investor, mirroring our approach when tracking the performance of bidders who are listed. Specifically, we assume that stock payments in takeovers are held in the stock of the acquiring firm and exchanges for other stock are held in the new stock. When shareholders receive cash payments (in mergers, liquidations, and bankruptcies) or CRSP cannot identify or does not cover the security in which payments are made, we track performance as if all proceeds were invested in the market portfolio, using the value-weighted CRSP index.

We merge the resulting monthly panel with the annual and the quarterly accounting data from CRSP-COMPUSTAT by assigning, to each monthly observation, the data pertaining to the most recent preceding fiscal-year (fiscal-quarter) end.

Our initial sample contains 623 bids and 293 takeover contests. We drop repeated bids by the same bidder, and keep the date of the first bid as the announcement date. This 
eliminates 20 bids. Next, we drop 57 contests that had not been completed by March 31, 2012. We further drop 99 bidders that could not be matched to a CRSP PERMNO. We then delete 14 contests in which the winner is the ultimate parent company of the target. Next, we balance the sample by requiring non-missing stock return data from $t=-35$ to $t=+36$ (i.e., from three years before to three years after the contest), which reduces the number of contests to 178 . We also eliminate one bidder which exhibits extreme stock returns and return volatility in the pre-merger period due to idiosyncratic factors. ${ }^{18}$ Finally, we keep only those contests for which we have stock price data for both the winner and the loser(s) in a given contest. This reduces the sample by another 66 contests, resulting in a final sample of 112 contests with bids placed by 233 bidders, 112 winners and 121 losers (Full Sample).

For the International Sample, we obtain the stock returns of non-North American firms in a three-step procedure. In the first step, we are able to match 59 non-North American firms with Compustat Global via the SEDOL identifier provided by Thomson One. The firms that cannot be matched with Compustat Global are then merged with Datastream, also using the SEDOL. We are able to match 13 firms in this second step. For the remaining firms, we search annual reports and company profiles for their company identifiers. If no SEDOL but the International Securities Identification Number (ISIN) can be found, the ISIN is used as identifier. Finally, we merge these firms with Datastream again, successfully matching another 18 firms. Daily Compustat Global and Datastream stock prices are compounded to monthly returns and adjusted for stock splits and dividends. Eventually, we are able to add 152 bids and 72 contests to our North American sample. ${ }^{19}$

\footnotetext{
18 This is the contest between Yahoo! Inc and TMP Worldwide Inc for HotJobs.com Ltd initiated by TMP Worldwide Inc on 29 June 2001 and won by Yahoo! Inc on February 13, 2002. Yahoo! Inc shows a $1000 \%$ stock price runup and reversal in the 36 months leading up to the merger, TMP Worldwide Inc shows a 100\% runup and reversal in the same period. Idiosyncratic factors determining the run-ups make these bidders a poor benchmark for each other. Keeping the observation in the sample does not affect the magnitude of our findings; it only increases the standard errors.

${ }^{19}$ We drop the contest between Volkswagen and General Motors for Skoda. According to Thomson One,
} 
the contest starts on 12th September 1990 and ended on the 12th December 1995. However, the corporate history states that a decision for Volkswagen was been made as early as December 1990. The discrepancy between Thomson One and the corporate history is possibly due to the structure of the merger. Skoda remained a joint venture between Volkswagen and the Czech Republic, and Volkswagen only increased its ownership share of the joint venture (above 50\%) on Dec 11, 1995. Hence, uncertainty about the outcome of the contest was resolved significantly before the official completion date. 


\section{Appendix: Figures and Tables}

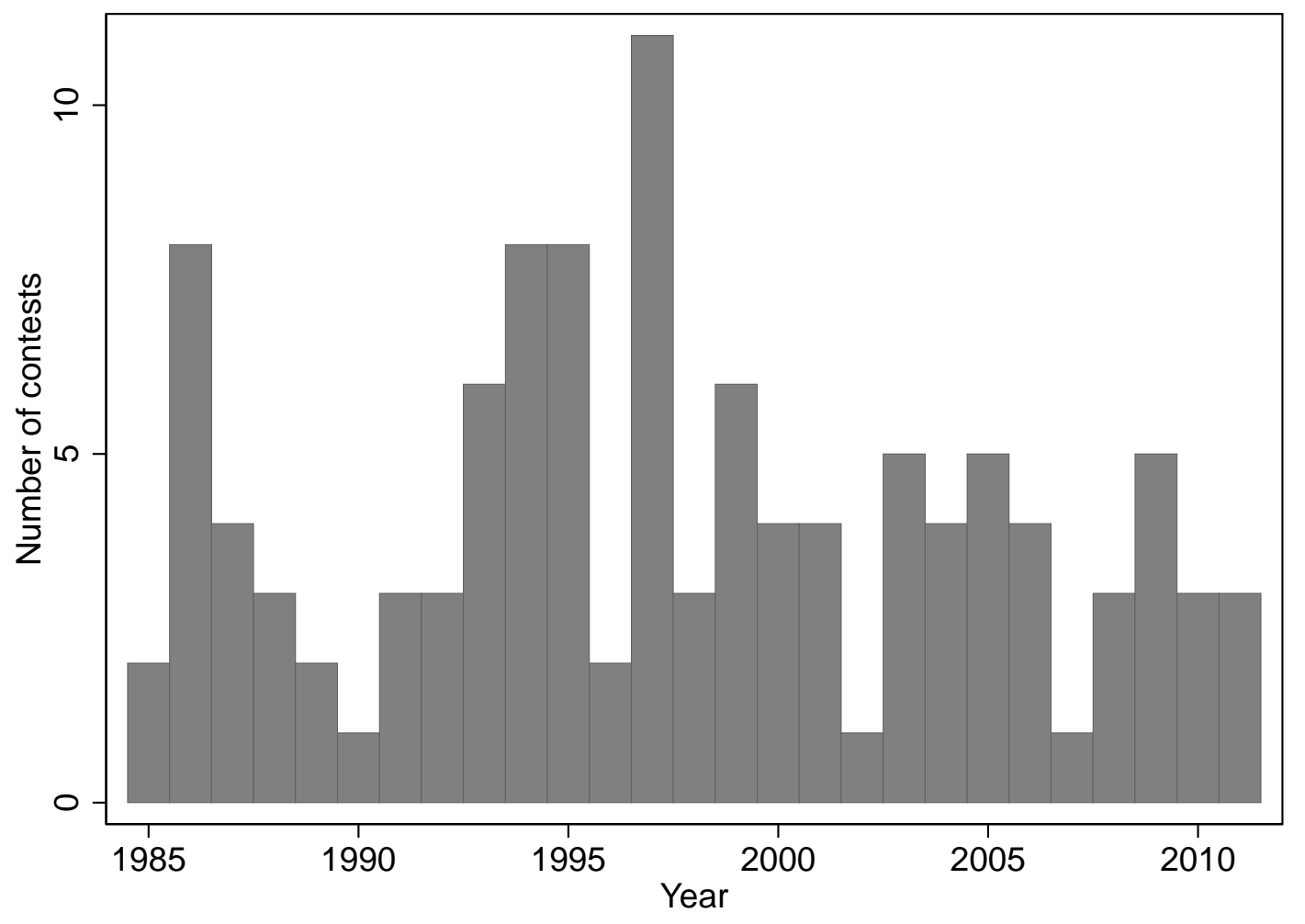

Figure A-1

Merger Contests over Time

This figure shows the frequency distribution of merger contests over the sample period. Years are the calendar years in which the contests started. 


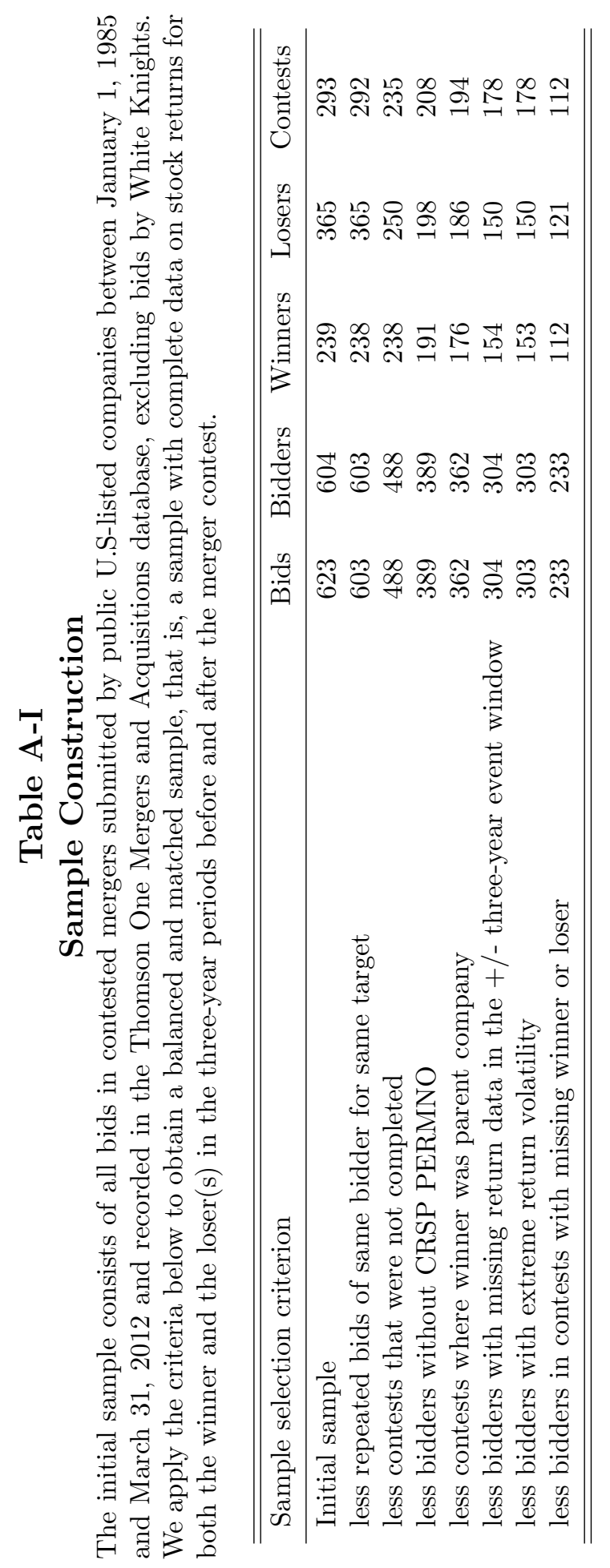




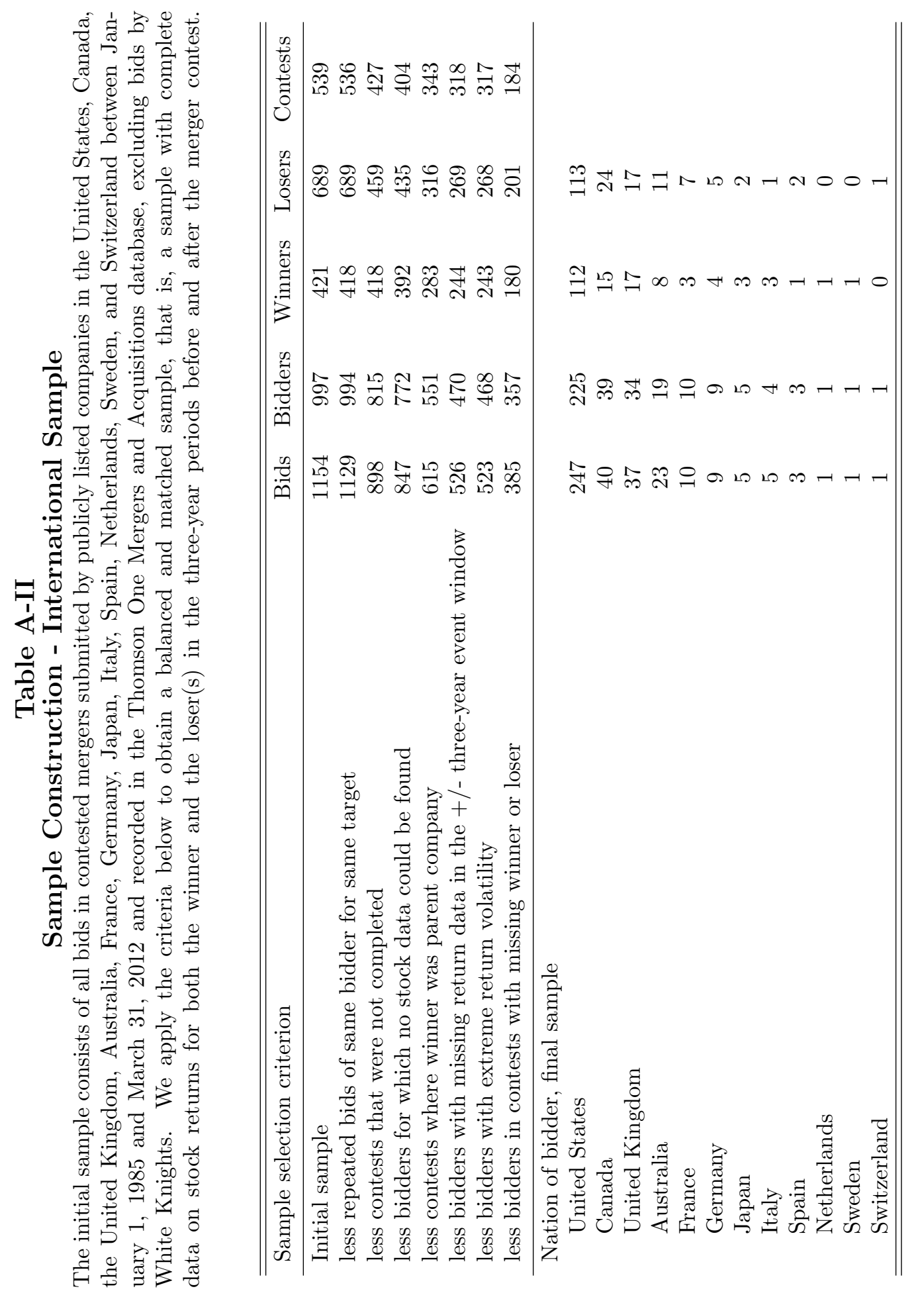




\section{Table A-III}

Winner-Loser Differences in Long-Run Abnormal Returns, Short Contests

The regression equation in all columns is: $B H A R_{i j t}=\alpha_{0}+\alpha_{1} W_{i j t}+\alpha_{2} t_{i j t}+\alpha_{3} t_{i j t} \cdot W_{i j t}+\alpha_{4}$ Post $_{i j t}+$ $\alpha_{5}$ Post $_{i j t} \cdot W_{i j t}+\alpha_{6} t_{i j t} \cdot$ Post $_{i j t}+\alpha_{7} t_{i j t} \cdot$ Post $_{i j t} \cdot W_{i j t}+\eta_{j}+\varepsilon_{i j t}$ (equation (3)). The regressions are run on the subsample of short (below-median) contest duration of the sample indicated in the first row. The dependent variable is the market-adjusted buy-and-hold abnormal return, normalized to zero in the month preceding the start of the contest and computed as $B H A R_{i j t}=\prod_{s=1}^{t}\left(1+r_{i j s}\right)-\prod_{s=1}^{t}\left(1+r_{s}^{m k t}\right)$ going forward in event time, and as $B H A R_{i j t}=\prod_{s=0}^{t+1}\left(1+r_{i j s}\right)^{-1}-\prod_{s=0}^{t+1}\left(1+r_{s}^{m k t}\right)^{-1}$ going backward, where $i$ denotes the bidder, $j$ the contest and $t$ the event month. The market return is the CRSP value-weighted market return. Winner $\left(W_{i j t}\right)$ is a dummy indicating whether bidder $i$ is a winner in merger contest $j . t$ is a variable counting event time. The dummy variable Post $_{i j t}$ indicates whether period $t$ is in the post-merger window of contest $j$. The lower part of the table between the two solid lines reports tests for the long-run winner-loser differences in BHARs at $t=+36$. Standard errors (in parentheses) are clustered by contest.

\begin{tabular}{lccc}
\hline \hline Sample: & $\begin{array}{c}\text { Full Sample } \\
(1)\end{array}$ & $\begin{array}{c}\text { Contest Coverage } \\
(2)\end{array}$ & $\begin{array}{c}\text { Intl. Sample } \\
(3)\end{array}$ \\
\hline Winner $\left(\alpha_{1}\right)$ & 1.110 & 2.767 & 2.549 \\
& $(2.423)$ & $(2.753)$ & $(1.990)$ \\
$\mathrm{t}\left(\alpha_{2}\right)$ & -0.117 & -0.151 & -0.177 \\
& $(0.177)$ & $(0.211)$ & $(0.155)$ \\
Winner $\times \mathrm{t}\left(\alpha_{3}\right)$ & 0.137 & 0.155 & $0.363^{* *}$ \\
& $(0.216)$ & $(0.265)$ & $(0.164)$ \\
Post $\left(\alpha_{4}\right)$ & -0.513 & 1.262 & 2.750 \\
& $(4.798)$ & $(5.922)$ & $(3.950)$ \\
Winner $\times$ Post $\left(\alpha_{5}\right)$ & -3.095 & -7.319 & -1.180 \\
& $(5.842)$ & $(7.016)$ & $(3.889)$ \\
$\mathrm{t} \times$ Post $\left(\alpha_{6}\right)$ & -0.457 & -0.491 & 0.292 \\
& $(0.377)$ & $(0.428)$ & $(0.270)$ \\
Winner $\times$ Post $\times \mathrm{t}\left(\alpha_{7}\right)$ & 0.415 & 0.577 & $-0.571^{*}$ \\
& $(0.501)$ & $(0.618)$ & $(0.293)$ \\
Contest fixed effects & Yes & Yes & Yes \\
\hline Merger effect at $t=36$ & 17.32 & 21.07 & -5.89 \\
Merger effect: $p$-value & 0.27 & 0.28 & 0.49 \\
\hline Observations & 8,208 & 6,480 & 13,680 \\
R-squared & 0.28 & 0.27 & 0.25 \\
Number of contests & 56 & 44 & 92 \\
\hline \hline
\end{tabular}

